\title{
РАРИТЕТНЫЕ ВИДЫ ФЛОРЫ И ФАУНЫ КАРАДАГСКОГО ПРИРОДНОГО ЗАПОВЕДНИКА
}

\author{
Костенко Н.С. \\ ФГБУН «Карадагская научная станџия им. Т.И.Вяземского - природный заповедник РАН», \\ 2. Феодосия, Российская Федераџия, karadag1914@mail.ru
}

\begin{abstract}
Приводится список растений, водорослей и грибов и животных, встречающихся на территории и акватории Карадагского природного заповедника, внесенных в Красную книгу Республики Крым (2015 а, 2015 б) и Красную книгу Российской Федерации (2001, 2008). На территории заповедника зарегистрировано 147 видов растений, водорослей и грибов, внесенных в Красную книгу Республики Крым (2015 а) и 193 вида животных, внесенных в Красную книгу Республики Крым (2015 б). В Красную книгу Российской Федерации (растения и грибы) (2008) внесено 49 видов и в Красную книгу Российской Федерации (животные) (2001) - 52. Среди раритетных видов сосудистых растений в Красную книгу Республики Крым внесены 19 видов эндемиков Крыма и 4 вида водорослей-макрофитов, являющихся эндемиками Средиземноморского бассейна. В Красную книгу Российской Федерации (2008) внесено 2 вида водорослей эндемиков Средиземноморского бассейна, включая Черное море.

Ключевые слова: Красная книга Республики Крым, Красная книга Российской Федерации, растения, водоросли, грибы, животные, раритетные виды, эндемики, Карадагский природный заповедник.
\end{abstract}

\section{Введение}

Еще до создания Карадагского государственного заповедника в 1976 году было начато тесное сотрудничество исследователей Карадагского отделения Института биологии южных морей АН УССР (бывшая Карадагская биологическая станция) с Главным ботаническим садом им. Н.В. Цицина, что позволило не только провести инвентаризацию местной флоры, но и затем начать планомерное обследование редких и исчезающих видов (Шатко, Миронова, 2004). Спустя почти 40 лет от момента начала изучения редких видов на Карадаге, был принят Закон Республики Крым «О Красной книге Республики Крым». Знаменательным событием в 2015 году явился выход в свет Красной книги Республики Крым (КК РК), которая была подготовлена с участием ученых Карадагского природного заповедника: ботаников кандидатов биологических наук В.В. Фатерыги, Л.П. Мироновой, И.Л. Потапенко, В.Ю. Летуховой, научного сотрудника М.Е. Кузнецова, зоологов - кандидатов биологических наук М.М. Бескаравайного, Ю.И. Будашкина, А.В. Фатерыги, научного сотрудника О.В. Кукушкина, редактирование которой было осуществлено кандидатом биологических наук, старшим научным сотрудником А.В. Фатерыгой (Карадагский природный заповедник). В появившейся недавно публикации (Мильчакова и др., 2015) приводятся неполные списки краснокнижных видов для Карадагского природного заповедника, которые содержат ряд неточностей относительно встречаемости на Карадаге некоторых видов флоры и фауны. Многими авторами очерков КК РК не всегда указывается местонахождение вида на Карадаге. В связи с этим возникла необходимость в составлении уточненного списка раритетной флоры и фауны Карадага, основанного на последних данных, реально отражающего картину биологического разнообразия заповедника.

\section{Методика исследований}

В работе использованы материалы Червоної книги України (тваринний світ) $(1994,2009)$, Красной книги Российской Федерации (2001, 2008), Красной книги Республики Крым (2015 а, 2015 б), аннотированные списки растений и животных Карадагского природного заповедника, материалы Летописи природы заповедника, а также личные сообщения ряда авторов. 


\section{Результаты и обсуждение}

Одним из необходимых условий создания Карадагского заповедника в 1979 году были оригинальность и богатство его флоры, наличие большого числа эндемичных, редких и исчезающих растений, сосредоточенных на небольшой территории (Шатко, 1979). Флора Карадагского природного заповедника достаточно хорошо изучена (Каменских, Миронова, 2004; Костенко и др., 2004; Шатко, Миронова, 2004; Партика, Нипорко, 2009; Саркина, Миронова, 2009, 2015, 2015 а; Миронова и др., 2012; Миронова, Фатерыга, 2015; Мильчакова и др., 2015; Войцехович, 2015; Войцехович, и др., 2015) и насчитывает 3140 видов. Из них сосудистые растения составляют 1165 видов (Миронова, Фатерыга, 2015), водоросли - 1005, лишайники - 346 (Войцехович и др., 2015), мохообразные - 82 (Партика, Нипорко, 2009). Среди 542 видов грибов, известных для Карадага, макромицеты составляют 285 (Саркина, Миронова, 2015 a).

Уникальность природы Карадага отражается в том, что здесь лесные виды соседствуют со степными, средиземноморские - с бореальными, горные - с равнинными (Шатко, Миронова, 2004). На Карадаге на площади 2065 га сосредоточена почти половина флористического богатства полуострова. Наиболее ценная часть флоры - эндемичные виды. На Карадаге известен 31 вид эндемичных сосудистых растений (Миронова, Фатерыга, 2015), из которых 19 представлены в КК РК (2015 а) (табл. 1). Среди них встречаются и карадагские эндемы.

Как было установлено еще около 40 лет назад, значительная часть видов флоры Карадага относится к редким и исчезающим (Шатко, 1979). На территории Карадагского природного заповедника обнаружено 147 видов растений, мхов, водорослей, лишайников и грибов, внесенных в КК РК. По систематическим группам они распределяются следующим образом: сосудистых растений - 116 видов, мохообразных - 3, водорослей-макрофитов - 12, лишайников - 8, макроскопических грибов - 8 видов. Четыре вида морских водорослей-макрофитов, внесенных в КК РК, являются эндемиками Средиземноморского бассейна (включая Черное море).

В Красной книге Российской Федерации (КК РФ) (2008) представлено 49 видов из Карадагского природного заповедника, среди которых сосудистые растения составляют 40 видов, водоросли - 3, лишайники - 3, грибы - 3 вида. Два вида водорослей, внесенных в КК РФ, являются эндемиками Средиземноморского бассейна (включая Черное море).

Сорок шесть видов растений, водорослей и грибов являются общими для КК РК и КК РФ.

Перечень раритетных видов растительного мира Карадагского природного заповедника приводится в таблице 1 .

Таблица 1.

Список видов растений, водорослей и грибов, занесенных в КК РК, КК РФ и эндемиков, произрастающих на территории и акватории Карадагского природного заповедника

\begin{tabular}{|c|c|c|c|c|c|}
\hline № & Виды и их систематическое положение & $\begin{array}{l}\frac{1}{a} \\
\Delta \\
s\end{array}$ & $\begin{array}{l}\theta \\
\Delta \\
\Delta\end{array}$ & 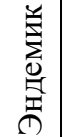 & Источник \\
\hline \multicolumn{6}{|c|}{ Сосудистые растения } \\
\hline \multicolumn{6}{|c|}{ Порядок многоножковые - Polypodiales } \\
\hline \multicolumn{6}{|c|}{ Семейство орляковые - Pteridaceae } \\
\hline 1 & Ложнопокровница марантовая - Notholaena marantae_(L.) Desv. & + & & & $\begin{array}{c}\text { Миронова, } \\
\text { Фатерыга, 2015 }\end{array}$ \\
\hline \multicolumn{6}{|c|}{ Порядок кипарисовые - Cupressales } \\
\hline \multicolumn{6}{|c|}{ Семейство кипарисовые - Cupressaceae } \\
\hline 2 & Можжевельник дельтовидный - Juniperus deltoides R.P. Adams & + & & & $\begin{array}{c}\text { Миронова, } \\
\text { Фатерыга, } 2015\end{array}$ \\
\hline 3 & Можжевельник высокий - Juniperus excelsa M. Bieb. & + & + & & $\begin{array}{c}\text { Миронова, } \\
\text { Фатерыга, 2015 }\end{array}$ \\
\hline
\end{tabular}


продолжение табл. 1

\begin{tabular}{|c|c|c|c|c|c|}
\hline \multicolumn{6}{|c|}{ Порядок сосновые - Pinales } \\
\hline \multicolumn{6}{|c|}{ Семейство сосновые - Pinaceae } \\
\hline 4 & $\begin{array}{l}\text { Сосна брутийская - Pinus brutia Ten. (P. stankewiczii (Sukacz.) Fomin, } \\
\text { P. pityusa Steven) }\end{array}$ & + & + & & $\begin{array}{c}\text { Миронова, } \\
\text { Фатерыга, 2015 }\end{array}$ \\
\hline 5 & Сосна Палласа - Pinus pallasiana D. Don (посадки) & & + & & $\begin{array}{c}\text { Миронова, } \\
\text { Фатерыга, } 2015\end{array}$ \\
\hline \multicolumn{6}{|c|}{ Порядок частухоцветные - Alismatales } \\
\hline \multicolumn{6}{|c|}{ Семейство взморниковые - Zosteraceae } \\
\hline 6 & Взморник морской - Zostera marina L. & + & & & $\begin{array}{l}\text { Костенко, } \\
1988\end{array}$ \\
\hline 7 & Взморник Нольта - Zostera noltei Hornem. & + & & & $\begin{array}{l}\text { Костенко, } \\
1988 \\
\end{array}$ \\
\hline \multicolumn{6}{|c|}{ Порядок сельдереецветные - Apiales } \\
\hline \multicolumn{6}{|c|}{ Семейство сельдерейные - Apiaceae } \\
\hline 8 & Морковница прибрежная - Astrodaucus littoralis (M. Bieb.) Drude & + & & & $\begin{array}{c}\text { Миронова, } \\
\text { Фатерыга, 2015 }\end{array}$ \\
\hline 9 & Синеголовник приморский - Eringium maritimum L. & + & + & & $\begin{array}{c}\text { Миронова, } \\
\text { Фатерыга, } 2015\end{array}$ \\
\hline 10 & Румия критмолистная - Rumia crithmifolia (Willd.) Koso-Pol. & + & & КЭ & $\begin{array}{c}\text { Миронова, } \\
\text { Фатерыга, } 2015\end{array}$ \\
\hline \multicolumn{6}{|c|}{ Порядок спаржецветные - Asparagales } \\
\hline \multicolumn{6}{|c|}{ Семейство амариллисовые - Amaryllidaceae } \\
\hline 11 & Лук Натальи - Allium nathaliae Seregin & + & & КЭ & $\begin{array}{c}\text { Миронова, } \\
\text { Фатерыга, 2015 }\end{array}$ \\
\hline 12 & $\begin{array}{l}\text { Лук Диоскорида - Allium siculum (Ucria) Lindl. subsp. dioscoridis (Sm.) } \\
\text { К. Richt. }\end{array}$ & + & & & $\begin{array}{c}\text { Миронова, } \\
\text { Фатерыга, 2015 }\end{array}$ \\
\hline 13 & Подснежник складчатый - Galanthus plicatus M. Bieb. & + & + & & $\begin{array}{c}\text { Миронова, } \\
\text { Фатерыга, 2015 }\end{array}$ \\
\hline \multicolumn{6}{|c|}{ Семейство спаржевые - Asparagaceae } \\
\hline 14 & $\begin{array}{l}\text { Бельвалия великолепная - Bellevalia speciosa Woronow ex Grossh. (=B. } \\
\text { sarmatica (Georgi) Woronow) }\end{array}$ & + & + & & $\begin{array}{c}\text { Миронова, } \\
\text { Фатерыга, 2015 }\end{array}$ \\
\hline 15 & Пролеска двулистная - Scilla bifolia L. & + & & & $\begin{array}{c}\text { Миронова, } \\
\text { Фатерыга, 2015 }\end{array}$ \\
\hline \multicolumn{6}{|c|}{ Семейство ирисовые - Iridaceae } \\
\hline 16 & Шафран Палласа - Crocus pallasii Goldb. & + & & & $\begin{array}{c}\text { Миронова, } \\
\text { Фатерыга, } 2015\end{array}$ \\
\hline 17 & Шафран прекрасный - Crocus speciosus M. Bieb. & + & + & & $\begin{array}{c}\text { Миронова, } \\
\text { Фатерыга, } 2015\end{array}$ \\
\hline 18 & Ирис низкий - Iris pumila L. & + & + & & $\begin{array}{c}\text { Миронова, } \\
\text { Фатерыга, } 2015\end{array}$ \\
\hline \multicolumn{6}{|c|}{ Семейство орхидные - Orchidaceae } \\
\hline 19 & $\begin{array}{l}\text { Анакамптис кавказский - Anacamptis morio (L.) R.M. Bateman, } \\
\text { Pridgeon et M.W. Chase subsp. caucasica (K. Koch) H. Kretzschmar, } \\
\text { Eccarius et H. Dietr. (=O. picta auct. non Loisel.) }\end{array}$ & + & + & & $\begin{array}{c}\text { Миронова, } \\
\text { Фатерыга, 2015 }\end{array}$ \\
\hline 20 & Анакамптис пирамидальный - Anacamptis pyramidalis (L.) Rich. & + & + & & $\begin{array}{c}\text { Миронова, } \\
\text { Фатерыга, } 2015\end{array}$ \\
\hline 21 & $\begin{array}{l}\text { Пыльцеголовник крупноцветковый - Cephalanthera damasonium } \\
\text { (Mill.) Druce }\end{array}$ & + & + & & $\begin{array}{c}\text { Миронова, } \\
\text { Фатерыга, 2015 }\end{array}$ \\
\hline 22 & Пыльцеголовник длиннолистный - Cephalanthera longifolia (L.) Fritsch & + & + & & $\begin{array}{c}\text { Миронова, } \\
\text { Фатерыга, } 2015\end{array}$ \\
\hline 23 & Пыльцеголовник красный - Cephalanthera rubra (L.) Rich. & + & + & & $\begin{array}{c}\text { Миронова, } \\
\text { Фатерыга, 2015 }\end{array}$ \\
\hline 24 & Пальчатокоренник римский - Dactylorhiza romana (Sebast.) Soó & + & & & $\begin{array}{c}\text { Миронова, } \\
\text { Фатерыга, } 2015\end{array}$ \\
\hline 25 & Дремлик морозниковый - Epipactis helleborine (L.) Crantz s.l. & + & & & $\begin{array}{c}\text { Миронова, } \\
\text { Фатерыга, } 2015\end{array}$ \\
\hline 26 & $\begin{array}{l}\text { Дремлик горно-крымский - Epipactis krymmontana Kreutz, Fateryga et } \\
\text { Efimov }\end{array}$ & + & & КЭ & $\begin{array}{l}\text { Фатерыга А., } \\
\text { Фатерыга В., 2015; } \\
\text { Фатерыга В., } \\
\text { Фатерыга А., } 2016 \\
\end{array}$ \\
\hline
\end{tabular}


продолэение табл. 1

\begin{tabular}{|c|c|c|c|c|c|}
\hline 27 & Дремлик мелколистный - Epipactis microphylla (Ehrh.) Sw. & + & & & $\begin{array}{c}\text { Миронова, } \\
\text { Фатерыга, 2015 }\end{array}$ \\
\hline 28 & Дремлик болотный - Epipactis palustris (L.) Crantz & + & & & $\begin{array}{c}\text { Миронова, } \\
\text { Фатерыга, } 2015\end{array}$ \\
\hline 29 & Ремнелепестник козий - Himantoglossum caprinum (M. Bieb.) Spreng. & + & + & & $\begin{array}{c}\text { Миронова, } \\
\text { Фатерыга, 2015 }\end{array}$ \\
\hline 30 & Лимодорум недоразвитый - Limodorum abortivum (L.) Sw. & + & + & & $\begin{array}{c}\text { Миронова, } \\
\text { Фатерыга, 2015 }\end{array}$ \\
\hline 31 & $\begin{array}{l}\text { Неотинея трехзубчатая - Neotinea tridentata (Scop.) R.M. Bateman, } \\
\text { Pridgeon et M.W. Chase (=Orchis tridentata Scop.) }\end{array}$ & + & + & & $\begin{array}{c}\text { Миронова, } \\
\text { Фатерыга, 2015 }\end{array}$ \\
\hline 32 & Гнездовка обыкновенная - Neottia nidus-avis (L.) Rich. & + & & & $\begin{array}{c}\text { Миронова, } \\
\text { Фатерыга, 2015 }\end{array}$ \\
\hline 33 & Офрис оводоносная - Ophrys oestrifera M. Bieb. & + & + & & $\begin{array}{c}\text { Миронова, } \\
\text { Фатерыга, 2015 }\end{array}$ \\
\hline 34 & Ятрышник мужской - Orchis mascula (L.) L. & + & + & & $\begin{array}{c}\text { Миронова, } \\
\text { Фатерыга, 2015 }\end{array}$ \\
\hline 35 & $\begin{array}{l}\text { Ятрышник Стевена - Orchis militaris L. subsp. stevenii (Rchb. f.) B. } \\
\text { Baumann et al. (=Orchis militaris auct. non L.) }\end{array}$ & + & + & & $\begin{array}{c}\text { Каменских, } \\
\text { Миронова, 2004 }\end{array}$ \\
\hline 36 & Ятрышник мелкоточечный - Orchis punctulata Steven ex Lindl. & + & + & & $\begin{array}{c}\text { Миронова, } \\
\text { Фатерыга, } 2015\end{array}$ \\
\hline 37 & Ятрышник пурпурный - Orchis purpurea Huds. & + & + & & $\begin{array}{c}\text { Миронова, } \\
\text { Фатерыга, 2015 }\end{array}$ \\
\hline 38 & Ятрышник обезьяний - Orchis simia Lam. & + & + & & $\begin{array}{c}\text { Миронова, } \\
\text { Фатерыга, 2015 }\end{array}$ \\
\hline 39 & Любка зеленоцветковая - Platanthera chlorantha (Custer) Rchb. & + & & & $\begin{array}{c}\text { Миронова, } \\
\text { Фатерыга, 2015 }\end{array}$ \\
\hline \multicolumn{6}{|c|}{ Семейство ксанторреевые - Xanthorrhoeaceae } \\
\hline 40 & Асфоделина крымская - Asphodeline taurica (Pall.) Endl. & + & + & & $\begin{array}{c}\text { Миронова, } \\
\text { Фатерыга, 2015 }\end{array}$ \\
\hline 41 & $\begin{array}{l}\text { Эремурус представительный - Eremurus spectabilis M. Bieb. s.1. (=E. } \\
\text { jungei Juz.) }\end{array}$ & + & + & & $\begin{array}{c}\text { Миронова, } \\
\text { Фатерыга, 2015 }\end{array}$ \\
\hline \multicolumn{6}{|c|}{ Порядок астроцветные - Asterales } \\
\hline \multicolumn{6}{|c|}{ Семейство астровые - Asteraceae } \\
\hline 42 & Пупавка бесплодная - Anthemis sterilis Steven s.l. & + & & кэ & $\begin{array}{c}\text { Миронова, } \\
\text { Фатерыга, 2015 }\end{array}$ \\
\hline 43 & Василек козий - Centaurea caprina Steven & + & & $\ni$ & $\begin{array}{c}\text { Миронова, } \\
\text { Фатерыга, } 2015\end{array}$ \\
\hline 44 & Ламира ежеголовая - Ptilostemon echinocephalus (Willd.) Greuter & + & & & $\begin{array}{c}\text { Миронова, } \\
\text { Фатерыга, 2015 }\end{array}$ \\
\hline \multicolumn{6}{|c|}{ Порядок бурачникоцветные - Boraginales } \\
\hline \multicolumn{6}{|c|}{ Семейство бурачниковые - Boraginaceae } \\
\hline 45 & Оносма многолистная - Onosma polyphylla Ledeb. & + & + & & $\begin{array}{c}\text { Миронова, } \\
\text { Фатерыга, 2015 }\end{array}$ \\
\hline \multicolumn{6}{|c|}{ Порядок капустоцветные - Brassicales } \\
\hline \multicolumn{6}{|c|}{ Семейство капустные - Brassicaceae } \\
\hline 46 & $\begin{array}{l}\text { Морская горчица черноморская - Cakile maritima Scop. subsp. euxina } \\
\text { (Pobed.) E.I. Nyárády }\end{array}$ & + & & & $\begin{array}{c}\text { Миронова, } \\
\text { Фатерыга, 2015 }\end{array}$ \\
\hline 47 & Конрингия булавовидная - Conringia clavata Boiss. & + & & & Рыфф, 2015 \\
\hline 48 & Катран шершавый - Crambe aspera M. Bieb. & + & & & $\begin{array}{c}\text { Миронова, } \\
\text { Фатерыга, 2015 }\end{array}$ \\
\hline 49 & Катран коктебельский - Crambe koktebelica (Junge) N. Busch & + & + & & $\begin{array}{c}\text { Миронова, } \\
\text { Фатерыга, 2015 }\end{array}$ \\
\hline 50 & Катран приморский - Crambe maritima L. & + & & & $\begin{array}{c}\text { Миронова, } \\
\text { Фатерыга, 2015 }\end{array}$ \\
\hline 51 & Катран перистый - Crambe pinnatifida W.T. Aiton & + & & & $\begin{array}{c}\text { Миронова, } \\
\text { Фатерыга, 2015 }\end{array}$ \\
\hline 52 & Катран Стевена - Crambe steveniana Rupr. & + & + & & $\begin{array}{c}\text { Миронова, } \\
\text { Фатерыга, 2015 }\end{array}$ \\
\hline 53 & Катран татарский - Crambe tataria Sebeók & + & & & $\begin{array}{c}\text { Миронова, } \\
\text { Фатерыга, } 2015\end{array}$ \\
\hline
\end{tabular}

(C) Н.С. Костенко, 2016

Труды Карадагской научной станции им. Т.И. Вяземского - природного заповедника РАН. - 2016. - Вып. 1 -59 - 
продолжение табл. 1

\begin{tabular}{|c|c|c|c|c|c|}
\hline 54 & Вечерница Стевена - Hesperis steveniana DC. & + & & & $\begin{array}{c}\text { Миронова, } \\
\text { Фатерыга, } 2015\end{array}$ \\
\hline 55 & Вайда прибрежная - Isatis littoralis Steven ex DC. & + & & & $\begin{array}{c}\text { Миронова, } \\
\text { Фатерыга, } 2015\end{array}$ \\
\hline \multicolumn{6}{|c|}{ Семейство каперсовые - Capparaceae } \\
\hline 56 & Каперсы травянистые - Capparis herbacea Willd. & + & & & $\begin{array}{c}\text { Миронова, } \\
\text { Фатерыга, 2015 }\end{array}$ \\
\hline \multicolumn{6}{|c|}{ Семейство клеомовые - Cleomaceae } \\
\hline 57 & $\begin{array}{l}\text { Клеоме сероватая - Cleome ornithopodioides L. subsp. canescens (DC.) } \\
\text { Tzvelev }\end{array}$ & + & & КЭ & $\begin{array}{c}\text { Миронова, } \\
\text { Фатерыга, 2015 }\end{array}$ \\
\hline \multicolumn{6}{|c|}{ Порядок гвоздикоцветные - Caryophyllales } \\
\hline \multicolumn{6}{|c|}{ Семейство гвоздичные - Caryophyllaceae } \\
\hline 58 & Ясколка Биберштейна - Cerastium biebersteinii DC. & + & & КЭ & $\begin{array}{c}\text { Миронова, } \\
\text { Фатерыга, } 2015\end{array}$ \\
\hline 59 & Ясколка болгарская - Cerastium bulgaricum Uechtr. & + & & & $\begin{array}{c}\text { Миронова, } \\
\text { Фатерыга, } 2015\end{array}$ \\
\hline 60 & Минуарция железистоволосистая - Minuartia adenotricha Schischk. & + & & КЭ & $\begin{array}{c}\text { Миронова, } \\
\text { Фатерыга, 2015 }\end{array}$ \\
\hline 61 & Минуарция черноморская - Minuartia euxina Klokov & + & & КЭ & $\begin{array}{c}\text { Миронова, } \\
\text { Фатерыга, } 2015\end{array}$ \\
\hline 62 & Минуарция крымская - Minuartia taurica (Steven) Graebn. & + & & КЭ & $\begin{array}{c}\text { Миронова, } \\
\text { Фатерыга, 2015 }\end{array}$ \\
\hline 63 & Приноготовник головчатый - Paronichia cephalotes (M. Bieb.) Besser & + & + & & $\begin{array}{c}\text { Миронова, } \\
\text { Фатерыга, } 2015\end{array}$ \\
\hline 64 & Смолевка приземистая - Silene supina M. Bieb. & + & & & $\begin{array}{c}\text { Миронова, } \\
\text { Фатерыга, 2015 }\end{array}$ \\
\hline \multicolumn{6}{|c|}{ Семейство гречишные - Polygonaceae } \\
\hline 65 & Курчавка отогнутая - Atraphaxis replicata Lam. & + & & & $\begin{array}{c}\text { Миронова, } \\
\text { Фатерыга, } 2015\end{array}$ \\
\hline 66 & $\begin{array}{l}\text { Щавель копьелистный - Rumex scutatus L. Subsp. hastifolius (M. Bieb.) } \\
\text { Borodina }\end{array}$ & + & & & $\begin{array}{c}\text { Миронова, } \\
\text { Фатерыга, } 2015\end{array}$ \\
\hline \multicolumn{6}{|c|}{ Порядок верескоцветные - Ericales } \\
\hline \multicolumn{6}{|c|}{ Семейство первоцветные - Primulaceae } \\
\hline 67 & $\begin{array}{l}\text { Цикламен коский - Cyclamen coum Mill. (интродуцирован в } \\
\text { заповеднике) }\end{array}$ & + & & & $\begin{array}{c}\text { Миронова, } \\
\text { Фатерыга, } 2015\end{array}$ \\
\hline \multicolumn{6}{|c|}{ Порядок бобовоцветные - Fabales } \\
\hline \multicolumn{6}{|c|}{ Семейство бобовые - Fabaceae } \\
\hline 68 & $\begin{array}{l}\text { Трагакант колючковый - Astragalus arnacantha M. Bieb. (=Astracantha } \\
\text { arnacantha (M. Bieb.) Podlech) }\end{array}$ & + & + & & $\begin{array}{c}\text { Миронова, } \\
\text { Фатерыга, } 2015\end{array}$ \\
\hline 69 & Астрагал понтийский - Astragalus ponticus Pall. & + & & & $\begin{array}{c}\text { Миронова, } \\
\text { Фатерыга, 2015 }\end{array}$ \\
\hline 70 & Астрагал изогнутый - Astragalus reduncus Pall. & + & & & $\begin{array}{c}\text { Миронова, } \\
\text { Фатерыга, 2015 }\end{array}$ \\
\hline 71 & Астрагал сверхуволосистый - Astragalus suprapilosus Gontsch. & + & & КЭ & $\begin{array}{c}\text { Миронова, } \\
\text { Фатерыга, 2015 }\end{array}$ \\
\hline 72 & Астрагал яичкоплодный - Astragalus testiculatus Pall. & + & & & $\begin{array}{c}\text { Миронова, } \\
\text { Фатерыга, 2015 }\end{array}$ \\
\hline 73 & Дрок беловатый - Genista albida Willd. & + & + & & $\begin{array}{c}\text { Миронова, } \\
\text { Фатерыга, 2015 }\end{array}$ \\
\hline 74 & Копеечник бледный - Hedysarum candidum M. Bieb. & + & + & & $\begin{array}{c}\text { Миронова, } \\
\text { Фатерыга, 2015 }\end{array}$ \\
\hline 75 & Копеечник крымский - Hedysarum tauricum Pall. Ex Willd. & + & & & $\begin{array}{c}\text { Миронова, } \\
\text { Фатерыга, 2015 }\end{array}$ \\
\hline 76 & Чечевица четковидная - Lens ervoides (Brign.) Grande & + & & & $\begin{array}{c}\text { Миронова, } \\
\text { Фатерыга, 2015 }\end{array}$ \\
\hline 77 & Эспарцет Палласа - Onobrychis pallasii (Willd.) M. Bieb. & + & & КЭ & $\begin{array}{c}\text { Миронова, } \\
\text { Фатерыга, } 2015\end{array}$ \\
\hline 78 & $\begin{array}{l}\text { Горох высокий - Pisum sativum L. subsp. elatius (M. Bieb.) Asch. et } \\
\text { Graebn. }\end{array}$ & + & & & $\begin{array}{c}\text { Миронова, } \\
\text { Фатерыга, } 2015\end{array}$ \\
\hline 79 & Горошек четкообразный - Vicia ervillia (L.) Willd. & + & & & $\begin{array}{c}\text { Миронова, } \\
\text { Фатерыга, 2015 }\end{array}$ \\
\hline
\end{tabular}

(C) Н.С. Костенко, 2016

Труды Карадагской научной станции им. Т.И. Вяземского - природного заповедника РАН. - 2016. - Вып. 1 
продолжение табл. 1

\begin{tabular}{|c|c|c|c|c|c|}
\hline \multicolumn{6}{|c|}{ Порядок горечавкоцветные - Gentianales } \\
\hline \multicolumn{6}{|c|}{ Семейство горечавковые - Gentianaceae } \\
\hline 80 & Блэкстония пронзеннолистная - Blackstonia perfoliata (L.) Huds. & + & & & $\begin{array}{c}\text { Миронова, } \\
\text { Фатерыга, 2015 }\end{array}$ \\
\hline \multicolumn{6}{|c|}{ Порядок гераниецветные - Geraniales } \\
\hline \multicolumn{6}{|c|}{ Семейство гераниевые - Geraniaceae } \\
\hline 81 & Герань клубневая - Geranium tuberosum L. & + & & & $\begin{array}{c}\text { Миронова, } \\
\text { Фатерыга, 2015 }\end{array}$ \\
\hline \multicolumn{6}{|c|}{ Порядок ясноткоцветные - Lamiales } \\
\hline \multicolumn{6}{|c|}{ Семейство яснотковые - Lamiaceae } \\
\hline 82 & Шалфей скабиозолистный - Salvia scabiosifolia Lam. s. 1. & + & & & $\begin{array}{c}\text { Миронова, } \\
\text { Фатерыга, 2015 }\end{array}$ \\
\hline 83 & $\begin{array}{l}\text { Железница блюдцевидная - Sideritis syriaca L. subsp. catillaris (Juz.) } \\
\text { Gladkova }\end{array}$ & + & & КЭ & $\begin{array}{c}\text { Миронова, } \\
\text { Фатерыга, } 2015\end{array}$ \\
\hline \multicolumn{6}{|c|}{ Семейство норичниковые - Scrophulariaceae } \\
\hline 84 & Цельзия восточная - Verbascum orientale (L.) All. & + & & & $\begin{array}{c}\text { Миронова, } \\
\text { Фатерыга, 2015 }\end{array}$ \\
\hline 85 & Коровяк перистораздельный - Verbascum pinnatifidum Vahl & + & & & $\begin{array}{c}\text { Миронова, } \\
\text { Фатерыга, } 2015\end{array}$ \\
\hline \multicolumn{6}{|c|}{ Порядок лилиецветные - Liliales } \\
\hline \multicolumn{6}{|c|}{ Семейство безвременниковые - Colchicaceae } \\
\hline 86 & Безвременник анкарский - Colchicum ancyrence B. L. Burtt & + & & & $\begin{array}{c}\text { Миронова, } \\
\text { Фатерыга, } 2015\end{array}$ \\
\hline 87 & Безвременник теневой - Colchicum umbrosum Steven & + & + & & $\begin{array}{c}\text { Миронова, } \\
\text { Фатерыга, } 2015\end{array}$ \\
\hline \multicolumn{6}{|c|}{ Семейство лилейные - Liliaceae } \\
\hline 88 & Тюльпан душистый - Tulipa suaveolens Roth (=T. schrenkii Regel) & + & + & & $\begin{array}{c}\text { Миронова, } \\
\text { Фатерыга, 2015 }\end{array}$ \\
\hline \multicolumn{6}{|c|}{ Порядок мальпигиецветные - Malpighiales } \\
\hline \multicolumn{6}{|c|}{ Семейство молочайные - Euphorbiaceae } \\
\hline 89 & Молочай прибрежный - Euphorbia paralias L. & + & & & $\begin{array}{c}\text { Миронова, } \\
\text { Фатерыга, } 2015\end{array}$ \\
\hline \multicolumn{6}{|c|}{ Семейство льновые - Linaceae } \\
\hline 90 & Лен Палласа - Linum pallasianum Schult. & + & & КЭ & $\begin{array}{c}\text { Миронова, } \\
\text { Фатерыга, } 2015\end{array}$ \\
\hline \multicolumn{6}{|c|}{ Порядок мальвоцветные - Malvales } \\
\hline \multicolumn{6}{|c|}{ Семейство мальвовые - Malvaceae } \\
\hline 91 & Липа пушистостолбиковая - Tilia dasystyla Steven & + & & & $\begin{array}{c}\text { Миронова, } \\
\text { Фатерыга, } 2015\end{array}$ \\
\hline \multicolumn{6}{|c|}{ Порядок миртоцветные - Myrtales } \\
\hline \multicolumn{6}{|c|}{ Семейство дербенниковые - Lythraceae } \\
\hline 92 & Дербенник тимьянолистный - Lythrum thymifolia L. & + & & & $\begin{array}{c}\text { Миронова, } \\
\text { Фатерыга, 2015 }\end{array}$ \\
\hline \multicolumn{6}{|c|}{ Порядок мятликоцветные - Poales } \\
\hline \multicolumn{6}{|c|}{ Семейство мятликовые - Poaceae } \\
\hline 93 & Пырей ковылелистный - Elytrigia stipifolia (Czern. Ex Nevski) Nevski & + & + & & $\begin{array}{c}\text { Миронова, } \\
\text { Фатерыга, } 2015\end{array}$ \\
\hline 94 & Пырей щетинистый - Elytrigia strigosa (M. Bieb.) Nevski & + & & КЭ & $\begin{array}{c}\text { Миронова, } \\
\text { Фатерыга, 2015 }\end{array}$ \\
\hline 95 & Ковыль волосатик - Stipa capillata L. & + & & & $\begin{array}{c}\text { Миронова, } \\
\text { Фатерыга, } 2015\end{array}$ \\
\hline 96 & $\begin{array}{l}\text { Ковыль камнелюбивый - Stipa eriocaulis Borb. Subsp. lithophila (P. } \\
\text { Smirn.) Tzvelev }\end{array}$ & + & & КЭ & $\begin{array}{c}\text { Миронова, } \\
\text { Фатерыга, 2015 }\end{array}$ \\
\hline 97 & Ковыль Лессинга - Stipa lessingiana Trin. et Rupr. s. 1. & + & & & $\begin{array}{c}\text { Миронова, } \\
\text { Фатерыга, } 2015\end{array}$ \\
\hline 98 & Ковыль понтийский - Stipa pontica P. Smirn. & + & & & $\begin{array}{c}\text { Миронова, } \\
\text { Фатерыга, 2015 }\end{array}$ \\
\hline 99 & Ковыль красивейший - Stipa pulcherrima K. Koch & + & + & & $\begin{array}{c}\text { Миронова, } \\
\text { Фатерыга, } 2015\end{array}$ \\
\hline 100 & Ковыль Сырейщикова - Stipa syreistschikowii P. Smirn. & + & + & & $\begin{array}{c}\text { Миронова, } \\
\text { Фатерыга, 2015 }\end{array}$ \\
\hline
\end{tabular}

(C) Н.С. Костенко, 2016

Труды Карадагской научной станции им. Т.И. Вяземского - природного заповедника РАН. - 2016. - Вып. 1 
продолэсение табл. 1

\begin{tabular}{|c|c|c|c|c|c|}
\hline 101 & Ковыль узколистный - Stipa tirsa Steven & + & & & $\begin{array}{c}\text { Миронова, } \\
\text { Фатерыга, } 2015\end{array}$ \\
\hline 102 & $\begin{array}{l}\text { Ковыль украинский - Stipa ucrainica P. Smirn. (=S. zalesskii auct. non } \\
\text { Wilensky) }\end{array}$ & + & + & & $\begin{array}{c}\text { Миронова, } \\
\text { Фатерыга, } 2015\end{array}$ \\
\hline \multicolumn{6}{|c|}{ Порядок лютикоцветные - Ranunculales } \\
\hline \multicolumn{6}{|c|}{ Семейство маковые - Papaveraceae } \\
\hline 103 & Мачок желтый - Glaucium flavum Crantz & + & + & & $\begin{array}{c}\text { Миронова, } \\
\text { Фатерыга, } 2015\end{array}$ \\
\hline \multicolumn{6}{|c|}{ Семейство лютиковые - Ranunculaceae } \\
\hline 104 & Адонис весенний - Adonis vernalis L. & + & & & $\begin{array}{c}\text { Миронова, } \\
\text { Фатерыга, 2015 }\end{array}$ \\
\hline 105 & $\begin{array}{l}\text { Живокость Палласа - Delphinium fissum Waldst. et Kit subsp. pallasii } \\
\text { (Nevski) Greuter et Burdet }\end{array}$ & + & & & $\begin{array}{c}\text { Миронова, } \\
\text { Фатерыга, 2015 }\end{array}$ \\
\hline 106 & $\begin{array}{l}\text { Прострел крымский - Pulsatilla halleri (All.) Willd. Subsp. taurica (Juz.) } \\
\text { K. Krause }\end{array}$ & + & & КЭ & $\begin{array}{c}\text { Миронова, } \\
\text { Фатерыга, 2015 }\end{array}$ \\
\hline \multicolumn{6}{|c|}{ Порядок розоцветные - Rosales } \\
\hline \multicolumn{6}{|c|}{ Семейство розовые - Rosaceae } \\
\hline 107 & Боярышник карадагский - Crataegus karadaghensis Pojark. & + & & & $\begin{array}{c}\text { Миронова, } \\
\text { Фатерыга, } 2015\end{array}$ \\
\hline 108 & Боярышник Мейера - Crataegus meyeri Pojark. & + & & & $\begin{array}{c}\text { Миронова, } \\
\text { Фатерыга, 2015 }\end{array}$ \\
\hline 109 & Боярышник Поярковой - Crataegus pojarkovae Kossych & + & & КЭ & $\begin{array}{c}\text { Миронова, } \\
\text { Фатерыга, 2015 }\end{array}$ \\
\hline 110 & Боярышник клинолистный - Crataegus sphaenophylla Pojark & + & & КЭ & $\begin{array}{c}\text { Миронова, } \\
\text { Фатерыга, 2015 }\end{array}$ \\
\hline 111 & Боярышник крымский - Crataegus taurica Pojark. & + & & & $\begin{array}{c}\text { Миронова, } \\
\text { Фатерыга, } 2015\end{array}$ \\
\hline 112 & Боярышник Турнефора - Crataegus tournefortii Griseb. & + & & & $\begin{array}{c}\text { Миронова, } \\
\text { Фатерыга, 2015 }\end{array}$ \\
\hline \multicolumn{6}{|c|}{ Порядок сапиндоцветные - Sapindales } \\
\hline \multicolumn{6}{|c|}{ Семейство сумаховые - Anacardiaceae } \\
\hline 113 & Фисташка туполистная - Pistacia mutica Fisch. et C.A. Меу. & + & + & & $\begin{array}{c}\text { Миронова, } \\
\text { Фатерыга, 2015 }\end{array}$ \\
\hline \multicolumn{6}{|c|}{ Семейство селитрянковые - Nitrariaceae } \\
\hline 114 & Селитрянка Шобера - Nitraria schoberi L. & + & & & Фатерыга В., 2015 \\
\hline \multicolumn{6}{|c|}{ Порядок камнеломкоцветные - Saxifragales } \\
\hline \multicolumn{6}{|c|}{ Семейство толстянковые - Crassulaceae } \\
\hline 115 & Очиток краснеющий - Sedum rubens L. & + & & & $\begin{array}{c}\text { Миронова, } \\
\text { Фатерыга, 2015 }\end{array}$ \\
\hline \multicolumn{6}{|c|}{ Семейство пионовые - Paeoniaceae } \\
\hline 116 & Пион крымский - Paeonia daurica Andrews & + & & & $\begin{array}{c}\text { Миронова, } \\
\text { Фатерыга, } 2015\end{array}$ \\
\hline 117 & Пион тонколистный - Paeonia tenuifolia L. & + & + & & $\begin{array}{c}\text { Миронова, } \\
\text { Фатерыга, 2015 }\end{array}$ \\
\hline \multicolumn{6}{|c|}{ Мохообразные } \\
\hline \multicolumn{6}{|c|}{ Порядок дикрановые мхи - Dicranales } \\
\hline \multicolumn{6}{|c|}{ Семейство поттиевые - Pottiaceae } \\
\hline 1 & Анектангиум Ханделя - Anoectangium handelii Schiffn. & + & & & $\begin{array}{c}\text { Партика, } \\
\text { Нипорко, } 2009\end{array}$ \\
\hline 2 & Дидимодон извилистый - Didymodon sinuosus (Mitt.) Delogne & + & & & $\begin{array}{c}\text { Партика, } \\
\text { Нипорко, } 2009\end{array}$ \\
\hline \multicolumn{6}{|c|}{ Порядок гипновые мхи - Hурnales } \\
\hline \multicolumn{6}{|c|}{ Семейство птерогониевые - Pterogoniaceae } \\
\hline 3 & Птерогониум стройный - Pterogonium gracile (Hedw.) Sm. & + & & & $\begin{array}{c}\text { Партика, } \\
\text { Нипорко, } 2009\end{array}$ \\
\hline \multicolumn{6}{|c|}{ Водоросли } \\
\hline \multicolumn{6}{|c|}{ Порядок бриопсиевые - Bryopsidales } \\
\hline \multicolumn{6}{|c|}{ Семейство бриопсиевые - Bryopsidaceae } \\
\hline 1 & $\begin{array}{l}\text { Бриопсис адриатический - Bryopsis cupressina var. adriatica (J. Agardh) } \\
\text { М. J. Wynne }\end{array}$ & + & & & $\begin{array}{l}\text { Мильчакова и др., } \\
2015\end{array}$ \\
\hline
\end{tabular}

(C) Н.С. Костенко, 2016

Труды Карадагской научной станции им. Т.И. Вяземского - природного заповедника РАН. - 2016. - Вып. 1 
продолжение табл. 1

\begin{tabular}{|c|c|c|c|c|c|}
\hline \multicolumn{6}{|c|}{ Семейство кодиевые - Codiaceae } \\
\hline 2 & Кодиум червеобразный - Codium vermilara (Olivi) Delle Chiaje & + & & & $\begin{array}{l}\text { Костенко и др., } \\
2004\end{array}$ \\
\hline \multicolumn{6}{|c|}{ Порядок кладофоровые - Cladophorales } \\
\hline \multicolumn{6}{|c|}{ Семейство кладофоровые - Cladophoraceae } \\
\hline 3 & Кладофора сивашская - Cladophora siwaschensis C. Meyer & + & & ач & $\begin{array}{l}\text { Костенко и др., } \\
2004\end{array}$ \\
\hline \multicolumn{6}{|c|}{ Порядок эктокарповые - Ectocarpales } \\
\hline \multicolumn{6}{|c|}{ Семейство хордариевые - Chordariaceae } \\
\hline 4 & Стилофора нежная - Stilophora tenella (Esper) P.C. Silva & + & + & & $\begin{array}{l}\text { Костенко и } \\
\text { др.,2004 }\end{array}$ \\
\hline \multicolumn{6}{|c|}{ Порядок фукусовые - Fucales } \\
\hline \multicolumn{6}{|c|}{ Семейство саргассовые - Sargassaceae } \\
\hline 5 & Цистозира бородатая - Cystoseira barbata (Stackh.) C. Agardh & + & & & $\begin{array}{l}\text { Костенко и др., } \\
2004\end{array}$ \\
\hline 6 & Цистозира косматая - Cystoseira crinita Duby & + & & & $\begin{array}{l}\text { Костенко и др., } \\
2004\end{array}$ \\
\hline \multicolumn{6}{|c|}{ Порядок спорохновые - Sporochnales } \\
\hline \multicolumn{6}{|c|}{ Семейство спорохновые - Sporochnaceae } \\
\hline 7 & Нерейя нитевидная - Nereia filiformis (J.Agardh) Zanard. & + & & & $\begin{array}{l}\text { Костенко и др., } \\
2004\end{array}$ \\
\hline \multicolumn{6}{|c|}{ Порядок церамиевые - Ceramiales } \\
\hline \multicolumn{6}{|c|}{ Семейство родомеловые - Rhodomelaceae } \\
\hline 8 & Лоренсия чашевидная - Laurencia coronopus J. Agardh & + & & $\mathrm{cч}$ & $\begin{array}{l}\text { Костенко и др., } \\
2004\end{array}$ \\
\hline 9 & Осмундея гибридная - Osmundea hybrida (DC.) K.W. Nam & + & & & $\begin{array}{l}\text { Костенко и др., } \\
2004\end{array}$ \\
\hline 10 & Осмундея перистонадрезная - Osmundea pinnatifida (Huds.) Stackh & + & & & $\begin{array}{l}\text { Костенко и др., } \\
2004\end{array}$ \\
\hline \multicolumn{6}{|c|}{ Порядок гигартиновые - Gigartinales } \\
\hline \multicolumn{6}{|c|}{ Семейство филлофоровые - Phyllophoraceae } \\
\hline 11 & Филлофора курчавая - Phyllophora crispa (Huds.) P. S. Dixon & + & + & $\mathrm{cч}$ & $\begin{array}{c}\text { Костенко и др., } \\
2004 \\
\end{array}$ \\
\hline \multicolumn{6}{|c|}{ Порядок родимениевые - Rhodymeniales } \\
\hline \multicolumn{6}{|c|}{ Семейство ломентариевые - Lomentariaceae } \\
\hline 12 & Ломентария сдавленная - Lomentaria compressa (Kutz.) Kylin & + & + & сч & $\begin{array}{l}\text { Костенко и др., } \\
2004\end{array}$ \\
\hline \multicolumn{6}{|c|}{ Лишайники } \\
\hline \multicolumn{6}{|c|}{ Порядок артониевые - Arthoniales } \\
\hline \multicolumn{6}{|c|}{ Семейство роччеловые - Rocellaceae } \\
\hline 1 & Рочелла водорослевидная - Rocella phycopsis Ach. & + & & & $\begin{array}{c}\text { Войцехович и др., } \\
2015\end{array}$ \\
\hline \multicolumn{6}{|c|}{ Порядок леканоровые - Lecanorales } \\
\hline \multicolumn{6}{|c|}{ Семейство лобариевые - Lobariaceae } \\
\hline 2 & Лобария легочница - Lobaria pulmonaria (L.) Hoffm. & + & + & & $\begin{array}{l}\text { Войцехович и др., } \\
2015\end{array}$ \\
\hline \multicolumn{6}{|c|}{ Семейство пармелиевые - Parmeliaceae } \\
\hline 3 & Летариелла перепутанная - Lethariella intricata (Moris) Krog & + & & & $\begin{array}{c}\text { Войцехович и др., } \\
2015\end{array}$ \\
\hline 4 & Неофусцелла грубоморщинистая - Neofuscelia ryssolea (Ach.) Essl. & + & & & $\begin{array}{l}\text { Войцехович и др., } \\
2015\end{array}$ \\
\hline 5 & Цетрария степная - Cetraria steppae (Savicz.) Karnef. & & + & & $\begin{array}{l}\text { Войцехович и } \\
\text { др.,2015 }\end{array}$ \\
\hline \multicolumn{6}{|c|}{ Семейство фисциевые - Physciaceae } \\
\hline 6 & Торнабея щитконосная - Tornabea scutellifera (With.) J.R. Laundon & + & + & & $\begin{array}{c}\text { Войцехович и др., } \\
2015\end{array}$ \\
\hline \multicolumn{6}{|c|}{ Семейство рамалиновые - Ramalinaceae } \\
\hline 7 & Рамалина канарская - Ramalina canariensis Steiner & + & & & $\begin{array}{l}\text { Войцехович и др., } \\
2015\end{array}$ \\
\hline 8 & Рамалина понтийская - Ramalina pontica Vezda & + & & & $\begin{array}{c}\text { Войцехович и др., } \\
2015\end{array}$ \\
\hline
\end{tabular}

(C) Н.С. Костенко, 2016

Труды Карадагской научной станции им. Т.И. Вяземского - природного заповедника РАН. - 2016. - Вып. 1 
продолжение табл. 1

\begin{tabular}{|c|c|c|c|c|}
\hline \multicolumn{5}{|c|}{ Порядок умбиликариевые - Umbilicariales } \\
\hline \multicolumn{5}{|c|}{ Семейство умбиликариевые - Umbilicariaceae } \\
\hline 9 & Умбиликария многолистная - Umbilicaria polyphylla (L.) Baumg. & + & & $\begin{array}{c}\text { Войцехович и др., } \\
2015\end{array}$ \\
\hline \multicolumn{5}{|c|}{ Грибы } \\
\hline \multicolumn{5}{|c|}{ Порядок пецицальные - Pezizales } \\
\hline \multicolumn{5}{|c|}{ Семейство пиронемовые - Pyronemataceae } \\
\hline 1 & Геопора купера - Geopora cooperi Harkn. & + & & $\begin{array}{c}\text { Саркина, } \\
\text { Миронова, } \\
2015 \text { а, б }\end{array}$ \\
\hline \multicolumn{5}{|c|}{ Семейство трюфелевые-Tuberaceae } \\
\hline 2 & Трюфель летний - Tuber aestivum Vitt. & + & + & $\begin{array}{c}\text { Саркина, } \\
\text { Миронова, } 2015\end{array}$ \\
\hline \multicolumn{5}{|c|}{ Порядок агарикальные - Agaricales } \\
\hline \multicolumn{5}{|c|}{ Семейство рядовковые-Tricholomataceae } \\
\hline 3 & $\begin{array}{l}\text { Флоккулярия желто-зеленая - Floccularia luteovirens (Alb. et Schwein.) } \\
\text { Pouzar. }\end{array}$ & + & & $\begin{array}{c}\text { Саркина, } \\
\text { Миронова, } \\
2015 \text { a } \\
\end{array}$ \\
\hline \multicolumn{5}{|c|}{ Порядок болетальные - Boletales } \\
\hline \multicolumn{5}{|c|}{ Семейство склеродермовые - Sclerodermataceae } \\
\hline 4 & Пизолит безкорневой - Pisolithus arhizus (Scop.) Rauschert & + & & $\begin{array}{c}\text { Саркина, } \\
\text { Миронова, } \\
2015 \text { a }\end{array}$ \\
\hline \multicolumn{5}{|c|}{ Порядок фаллальные - Phallales } \\
\hline \multicolumn{5}{|c|}{ Семейство фаллюсовые - Phallaceae } \\
\hline 5 & Решеточник красный - Clathrus ruber R.Micheli ex Pers. & + & + & $\begin{array}{c}\text { Саркина, } \\
\text { Миронова, } 2015\end{array}$ \\
\hline \multicolumn{5}{|c|}{ Порядок полипоральные - Polyporales } \\
\hline \multicolumn{5}{|c|}{ Семейство ганодермовые - Ganodermataceae } \\
\hline 6 & Трутовик лакированный - Ganoderma lucidum (Curtis) R. Carst & + & + & $\begin{array}{c}\text { Саркина, } \\
\text { Миронова, } \\
2015 \mathrm{a} \\
\end{array}$ \\
\hline \multicolumn{5}{|c|}{ Порядок руссулальные - Russulales } \\
\hline \multicolumn{5}{|c|}{ Семейство герициевые - Hericiaceae } \\
\hline 7 & Гериций коралловидный - Hericium coralloides (Fr.) Gray & + & & $\begin{array}{c}\text { Саркина, } \\
\text { Миронова, } \\
2015 \mathrm{a} \\
\end{array}$ \\
\hline \multicolumn{5}{|c|}{ Семейство сыроежковые - Russulaceae } \\
\hline 8 & Рыжик кроваво-красный - Lactarius sanguifluus (Paulet) Fr. & + & & $\begin{array}{c}\text { Саркина, Миронова, } \\
2015 \text { а, б }\end{array}$ \\
\hline
\end{tabular}

Примечание к таблице: кэ - крымский эндемик, сч - эндемик Средиземноморского бассейна (включая Черное море), ач - эндемик Азово-черноморского бассейна.

Из 1165 видов сосудистых растений Карадага (Миронова, Фатерыга, 2015), 116 внесено в КК РК, что составляет 9,9 \% от его флористического состава. По отношению к видам сосудистых растений КК РК участие карадагской флоры составляет 39,3\%. Наиболее богато видами семейство орхидных, полностью представленное в КК РК (21 вид), среди них недавно описанный крымский эндемик дремлик горно-крымский (Fateryga et al., 2014; Фатерыга B., Фатерыга А., 2016). На втором месте - семейство бобовых - 12, на третьем - мятликовые и капустные (по 10 видов). Остальные семейства карадагских растений представлены в КК РК 1-7 видами.

Из 82 видов мхов, произрастающих на Карадаге, 3 внесены в КК РК, что составляет 8,5 \% краснокнижной флоры Крыма. Из 285 таксонов макромицетов, обнаруженных на Карадаге (Саркина, Миронова, 2015 а), в КК РК внесено 8 видов, что составляет 24,2 \% краснокнижных грибов Крыма (33 вида).

Из 346 видов лишайников, найденных на Карадаге, 8 видов внесены в КК РК, что составляет 36,3\% от краснокнижной флоры Крыма (22 вида). 
Из 178 видов водорослей-макрофитов, зарегистрированных в акватории Черного моря у Карадага, 12 внесены в КК РК, что составляет 66,7 \% краснокнижной флоры черноморских водорослей (18 видов).

Согласно приведенным данным (табл. 1) в Карадагском природном заповеднике зарегистрировано 147 видов растений, водорослей и грибов, внесенных в КК РК, что составляет 36,7 \% от краснокнижной флоры Крыма.

Фотоизображения раритетных видов флоры Карадага представлены на рисунках 1, 3 .

Фауна Карадага достаточно хорошо изучена (Бескаравайный, Шевченко, 1989; Будашкин, 2004; Гринцов, 2004; Гринцов и др., 2004; Загородняя и др., 2004; Иванов и др., 2004, 2009, 2015; Костенко, Шаганов, 2004; Ревков и др., 2004; Годлевская и др., 2009; Кукушкин, 2010, 2010 a, 2011; Котенко, Кукушкин, 2010; Бескаравайный, 2011, 2012, 2013, 2016;). Из 5500 видов животных, известных для Карадага, в КК РК внесено 193, из них 6 - моллюски, 92 членистоногие, 95 видов - хордовые. В КК РФ внесено 52 вида животных, из них 7 членистоногие, 45 - хордовые.

Сведения о систематическом составе охраняемых животных приведены в таблице 2.

Таблица 2.

Список видов животного мира, занесенных в КК РК, КК РФ и эндемиков, обитающих на территории и акватории Карадагского природного заповедника

\begin{tabular}{|c|c|c|c|c|c|}
\hline № & Виды и их систематическое положение & $\begin{array}{l}\frac{y}{2} \\
\frac{1}{2} \\
0\end{array}$ & $\begin{array}{l}\theta \\
\theta \\
\Delta y \\
\Delta y\end{array}$ & 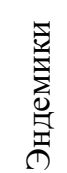 & Источник \\
\hline \multicolumn{6}{|c|}{ Тип моллюски - Mollusca } \\
\hline \multicolumn{6}{|c|}{ Класс двустворчатые - Bivalvia } \\
\hline \multicolumn{6}{|c|}{ Отряд устрицы - Ostreoida } \\
\hline 1 & Устрица европейская - Ostrea edulis Linnaeus, 1758 & + & & & Ревков и др., 2004 \\
\hline \multicolumn{6}{|c|}{ Отряд морские гребешки - Pectinoida } \\
\hline 2 & $\begin{array}{l}\text { Гребешок черноморский - Flexopecten glaber ponticus Bucquoy, } \\
\text { Dautzenberg et Dollfus, } 1889\end{array}$ & + & & эч & Ревков и др., 2004 \\
\hline \multicolumn{6}{|c|}{ Отряд венериды - Veneroida } \\
\hline 3 & Гастрана хрупкая - Gastrana fragilis (Linnaeus, 1758) & + & & & Ревков и др., 2004 \\
\hline 4 & Донацилла роговая - Donacilla cornea (Poli, 1791) & + & & & Ревков и др., 2004 \\
\hline \multicolumn{6}{|c|}{ Класс брюхоногие - Gastropoda } \\
\hline \multicolumn{6}{|c|}{ Отряд древние брюхоногие - Archaeogastropoda } \\
\hline 1 & Морское блюдечко - Patella ulyssiponensis Gmelin, 1791 & + & & & Ревков и др., 2004 \\
\hline \multicolumn{6}{|c|}{ Отряд стебельчатоглазые - Stylommatophora } \\
\hline 2 & Улитка крымская - Helix lucorum taurica Krinicky, 1833 & + & & кэ & Леонов, 2015 \\
\hline \multicolumn{6}{|c|}{ Тип членистоногие - Arthropoda } \\
\hline \multicolumn{6}{|c|}{ Класс высшие раки - Malacostraca } \\
\hline \multicolumn{6}{|c|}{ Отряд десятиногие раки - Decapoda } \\
\hline 1 & Краб каменный - Eriphia verrucosa Forscal, 1775 & + & & & Гринцов и др., 204 \\
\hline 2 & Краб мраморный - Pachygrapsus marmoratus Fabricius, 1787 & + & & & Гринцов и др., 2004 \\
\hline 3 & Лисмата щетинконогая - Lysmata seticaudata (Risso, 1816) & + & & & Гринцов и др., 2004 \\
\hline \multicolumn{6}{|c|}{ Класс челюстеногие раки - Maxillopoda } \\
\hline \multicolumn{6}{|c|}{ Отряд каляниды - Calanoida } \\
\hline 1 & Аномалоцера Патерсона - Anomalocera patersoni Templeton, 1837 & + & & & $\begin{array}{l}\text { Загородняя и др., } \\
2004\end{array}$ \\
\hline 2 & Лабидоцера бурая - Labidocera brunescens (Czerniavski, 1868) & + & & & $\begin{array}{c}\text { Загородняя и др., } \\
2004\end{array}$ \\
\hline 3 & Понтелла средиземноморская - Pontella mediterranea (Claus, 1863) & + & & & $\begin{array}{l}\text { Загородняя и др., } \\
2004\end{array}$ \\
\hline \multicolumn{6}{|c|}{ Класс паукообразные - Arachnida } \\
\hline \multicolumn{6}{|c|}{ Отряд сольпуги - Solifugae } \\
\hline 1 & Сольпуга обыкновенная - Galeodes araneoides (Pallas, 1772) & + & & & $\begin{array}{l}\text { Ястребцов, } 1994 \text { a; } \\
\text { Кукушкин, } 2013\end{array}$ \\
\hline
\end{tabular}

Труды Карадагской научной станции им. Т.И. Вяземского - природного заповедника РАН. - 2016. - Вып. 1 
продолжение табл.2

\begin{tabular}{|c|c|c|c|c|c|}
\hline 2 & Скорпион крымский - Euscorpius tauricus (C.L.Koch, 1837) & + & & & $\begin{array}{c}\text { Ястребцов, } 1994 \text { б; } \\
\text { Будашкин, личное } \\
\text { сообщение; } \\
\text { Гордеева, личное } \\
\text { сообщение }\end{array}$ \\
\hline \multicolumn{6}{|c|}{ Класс насекомые - Insecta } \\
\hline \multicolumn{6}{|c|}{ Отряд стрекозы - Odonata } \\
\hline 1 & Красотка крымская - Calopterix splendens taurica Selys, 1853 & + & & КЭ & $\begin{array}{l}\text { Будашкин, личное } \\
\text { сообщение }\end{array}$ \\
\hline 2 & $\begin{array}{l}\text { Меднолютка мелкозубчатая - Chalcolestes parvidens (Artobelevski, } \\
\text { 1929) }\end{array}$ & + & & & $\begin{array}{l}\text { Будашкин, личное } \\
\text { сообщение }\end{array}$ \\
\hline 3 & Дозорщик-император - Anax imperator Leach, 1815 & + & + & & $\begin{array}{l}\text { Будашкин, личное } \\
\text { сообщение }\end{array}$ \\
\hline \multicolumn{6}{|c|}{ Отряд таракановые - Dictyoptera } \\
\hline 4 & Эмпуза полосатая - Empusa fasciata Brulle, 1832 & + & & & Срмоленко, 1994 a \\
\hline 5 & Боливария короткокрылая - Bolivaria brachyptera (Pallas, 1773) & + & & & $\begin{array}{c}\text { Пушкар, Срмоленко, } \\
2009 \\
\end{array}$ \\
\hline 6 & Ирис пятнистокрылый - Iris polystictica (Fischer-Waldheim, 1846) & + & & & Срмоленко,1994 б \\
\hline \multicolumn{6}{|c|}{ Отряд прямокрылые - Orthoptera } \\
\hline 7 & Сверчок византийский - Pseudomogoplistes byzantius Gorochov, 1995 & + & & & Горохов, 2015 a \\
\hline 8 & Анадримадуза Ретовского - Anadrymadusa retowskii (Adelung, 1907) & + & & кЭ & $\begin{array}{l}\text { Пушкар, Назаренко, } \\
\text { Срмоленко, } 2009\end{array}$ \\
\hline 9 & Пилохвост Плигинского - Poecilimon pliginskii Miram, 1929 & + & & кэ & Срмоленко, 1994 в \\
\hline 10 & Дыбка степная - Saga pedo (Pallas, 1771) & + & + & & Горохов, 2015 б \\
\hline 11 & $\begin{array}{l}\text { Кобылка крестовая крымская - Paracyptera microptera jailensis Miram, } \\
1927\end{array}$ & + & & кэ & Горохов, 2015 в \\
\hline \multicolumn{6}{|c|}{ Отряд эмбии - Embioptera } \\
\hline 12 & Эмбия реликтовая - Haploembia solieri (Rambur, 1842) & + & & & Срмоленко, 1994; \\
\hline \multicolumn{6}{|c|}{ Отряд жесткокрылые - Coleoptera } \\
\hline 13 & Красотел пахучий - Calosoma sycophanta (Linnaeus, 1758) & + & + & & $\begin{array}{c}\text { Пучков, Мосякин, } \\
2015 \\
\end{array}$ \\
\hline 14 & Жужелица венгерская - Carabus hungaricus (Fabricius, 1792) & + & + & & Пучков, 2006 \\
\hline 15 & $\begin{array}{l}\text { Жужелица шероховатая крымская-Carabus scabrosus tauricus (Bonelli, } \\
\text { 1811) }\end{array}$ & + & & Кэ & $\begin{array}{l}\text { Мосякин, Пучков, } \\
2015\end{array}$ \\
\hline 16 & Стафилин волосатый - Emus hirtus (Linnaeus, 1758) & + & & & Мосякин, 2015 а \\
\hline 17 & Стафилин короткокрылый - Ocypus curtipennis (Motschulsky, 1849) & + & & & Мосякин, 2015 б \\
\hline 18 & Жук-олень - Lucanus cervus (Linnaeus, 1758) & + & + & & $\begin{array}{c}\text { Мартынов, } \\
\text { Мосякин, } 2015\end{array}$ \\
\hline 19 & Бронзовка особенная - Protaetia speciosa (Adams, 1817) & + & & & $\begin{array}{l}\text { Будашкин, личное } \\
\text { сообщение }\end{array}$ \\
\hline 20 & Скрытоглав двуцветный - Cryptocephalus biguttulus Suffrian, 1848 & + & & & Мосякин, 2015 в \\
\hline 21 & Усач большой дубовый - Cerambix cerdo Linnaeus, 1758 & + & & & $\begin{array}{l}\text { Мирошников, } \\
\text { Бартенев, } 2015\end{array}$ \\
\hline 22 & Усач-краснокрыл Ренивона - Purpuricenus renyvonae Slama, 2001 & + & & & $\begin{array}{c}\text { Прокопов, } \\
\text { Турбанов, } 2015\end{array}$ \\
\hline 23 & Розалия альпийская - Rosalia alpina (Linnaeus, 1758) & + & + & & $\begin{array}{c}\text { Будашкин, личное } \\
\text { сообщение }\end{array}$ \\
\hline 24 & Брахицерус грязный - Brachycerus lutulentus Gullenchal, 1833 & + & & Кэ & Турбанов, 2015 \\
\hline 25 & Леукомигус белоснежный - Leucomigus candidatus (Pallas, 1771) & + & & & $\begin{array}{l}\text { Бровдій, Воловник, } \\
1994 \\
\end{array}$ \\
\hline 26 & Ликсус катрановый - Lixus canescens (Fischer-Waldheim, 1835) & + & & & $\begin{array}{c}\text { Будашкин, личное } \\
\text { сообщение }\end{array}$ \\
\hline \multicolumn{6}{|c|}{ Отряд сетчатокрылые - Neuroptera } \\
\hline 27 & Кривошпор западный - Acanthaclisis occitanica (Villers, 1789) & + & & & $\begin{array}{l}\text { Кривохатский, } \\
\text { Прокопов, } 2015 \mathrm{a}\end{array}$ \\
\hline 28 & Невролеон сходный - Neuroleon microstenus propinquus (Navas, 1911) & + & & & $\begin{array}{l}\text { Кривохатский, } \\
\text { Прокопов, } 2015 \text { б }\end{array}$ \\
\hline 29 & Шпорник бэтийский - Synclisis baetica (Rambur, 1842) & + & & & $\begin{array}{l}\text { Кривохатский, } \\
\text { Прокопов, } 2015 \text { в }\end{array}$ \\
\hline
\end{tabular}


продолжение табл.2

\begin{tabular}{|c|c|c|c|}
\hline 30 & $\begin{array}{l}\text { Бабочник колыванский - Libelloides macaronius kolyvanensis (Laxmann, } \\
\text { 1842) }\end{array}$ & + & $\begin{array}{c}\text { Єрмоленко, } \\
\text { Котенко, Кукушкин, } \\
2009\end{array}$ \\
\hline 31 & Мантиспа штирийская - Mantispa styriaca (Poda, 1761) & + & $\begin{array}{c}\text { Захаренко, Котенко, } \\
2009 \\
\end{array}$ \\
\hline \multicolumn{4}{|c|}{ Отряд чешуекрылые - Lepidoptera } \\
\hline 32 & Пестрянка веселая - Zygaena laeta (Hubner, [1790]) & + & Будашкин, 2004 \\
\hline 33 & Пестрянка понтийская - Zygaena sedyi Fabricius, 1787 & + & Будашкин, 2004 \\
\hline 34 & Древоточец колхидский - Stygioides colchica (Herrich-Schaffer, 1851) & + & Будашкин, 2004 \\
\hline 35 & Шелкопряд Баллиона - Lemonia ballioni (Christoph, 1888) & + & Будашкин, 2004 \\
\hline 36 & Бражник карликовый - Sphingonaepiopsis gorgoniades (Hubner, [1819]) & + & Будашкин, 2004 \\
\hline 37 & Бражник олеандровый - Daphnis nerii (Linnaeus, 1758) & + & Будашкин, 1989 \\
\hline 38 & Бражник Прозерпина - Proserpinus proserpina (Pallas, 1772) & + & Будашкин, 2004 \\
\hline 39 & Бражник скабиозовый - Hemaris tityus (Linnaeus, 1758) & + & Будашкин, 2004 \\
\hline 40 & Бражник хорватский - Hemaris croatica (Esper, [1800]) & + & Будашкин, 2004 \\
\hline 41 & Эублемма порядочная - Eublemma pudorina (Staudinger, 1889) & + & $\begin{array}{c}\text { Будашкин, } \\
2015 \text { a }\end{array}$ \\
\hline 42 & $\begin{array}{l}\text { Совка червецовая - Calymma communimacula ([Denis et Schiffermuller], } \\
\text { 1775) }\end{array}$ & + & Будашкин, 2004 \\
\hline 43 & Ленточница большая красная - Catocala dilecta (Hubner, [1808]) & + & Будашкин, 2004 \\
\hline 44 & Ленточница голубая - Catocala fraxini (Linnaeus, 1758) & + & Будашкин, 2004 \\
\hline 45 & Ленточница рыжая - Catocala diversa (Geyer, [1828]) & + & Будашкин, 2004 \\
\hline 46 & Капюшонница серебристая - Cucullia argentina (Fabricius, 1787) & + & Будашкин, 2004 \\
\hline 47 & Совка розовая - Aedophron rhodites (Eversmann, 1851) & + & $\begin{array}{l}\text { Будашкин, } \\
20156\end{array}$ \\
\hline 48 & Совка Трейчке - Periphanes treitschkei (Frivaldsky, 1835) & + & Будашкин, 2004 \\
\hline 49 & Совка мрачная - Mormo maura (Linnaeus, 1758) & + & $\begin{array}{l}\text { Будашкин, } \\
2015 \text { в }\end{array}$ \\
\hline 50 & Медведица пятнистая - Chelis maculosa (Gerning, 1780) & + & $\begin{array}{c}\text { Ефетов, } \\
\text { Будашкин, } 1990 \\
\end{array}$ \\
\hline 51 & Поликсена - Zerinthia polyxena ([Denis et Schiffermuller], 1775) & + & Будашкин, 2004 \\
\hline 52 & MaxaoH - Papilio machaon (Linnaeus, 1758) & + & Будашкин, 2004 \\
\hline 53 & Хвостатка вязовая - Nordmannia w-album (Knoch, 1782) & + & Будашкин, 2015 г \\
\hline 54 & Каллимах - Tomares callimachus (Eversmann, 1848) & + & Будашкин, 2004 \\
\hline \multicolumn{4}{|c|}{ Отряд перепончатокрылые - Hymenoptera } \\
\hline 55 & Стефанус зубценосный - Stephanus serrator (Fabricius, 1798) & + & $\begin{array}{l}\text { Фатерыга А., } \\
2015 \text { a }\end{array}$ \\
\hline 56 & Гедихрум зеленый - Hedychrum virens Dahlbom, 1845 & + & $\begin{array}{c}\text { Фатерыга А., } \\
2015 \text { б } \\
\end{array}$ \\
\hline 57 & Стильбум зеленоватый - Stilbum cyanurum (Forster, 1771) & + & $\begin{array}{l}\text { Фатерыга А., } \\
2015 \text { в }\end{array}$ \\
\hline 58 & Сколия-гигант - Megascolia maculata (Drury, 1773) & + & Иванов и др., 2015 \\
\hline 59 & Целонитес крымский - Celonites abbreviatus tauricus Kostylev, 1935 & + & Иванов и др., 2015 \\
\hline 60 & Паравеспа царская - Paravespa rex (von Schulthes, 1924) & + & Иванов и др., 2015 \\
\hline 61 & Криптохил кольчатый - Cryptocheilus annulatus (Fabricius, 1798) & + & Иванов и др., 2015 \\
\hline 62 & Криптохил красноватый - Cryptocheilus rubellus (Eversmann, 1846) & + & Иванов и др., 2015 \\
\hline 63 & Аммофила сарептская - Ammophila sareptana Kohl, 1884 & + & Иванов и др., 2015 \\
\hline 64 & Бембикс оливковый - Bembix olivacea Fabricius, 1787 & + & Шоренко, 2015 \\
\hline 65 & Церцерис бугорчатая - Cerceris tuberculata (Villers, 1787) & + & Иванов и др., 2015 \\
\hline 66 & Лярра анафемская - Larra anathema (Rossi, 1790) & + & Иванов и др., 2015 \\
\hline 67 & Стизус двухточечный - Stizus bipunctatus (F. Smith, 1856) & + & Иванов и др., 2015 \\
\hline 68 & Андрена большая - Andrena magna Warncke, 1965 & + & Иванов и др., 2015 \\
\hline 69 & Андрена краснопятнистая - Andrena stigmatica Morawitz, 1895 & + & Иванов и др., 2015 \\
\hline 70 & Пчела-листорез белополосая - Megachile albisecta (Klug, 1817) & + & Иванов и др., 2009 \\
\hline 71 & Пчела-каменщица Лефебвра - Megachile lefebvrei Lepeletier, 1841 & + & Иванов и др., 2015 \\
\hline 72 & Трахуза скабиозовая - Trachusa interrupta (Fabricius, 1781) & + & Иванов и др., 2009 \\
\hline 73 & Трахуза опушенная - Trachusa pubescens (Morawitz, 1872) & + & Иванов и др., 2015 \\
\hline 74 & Шмель глинистый - Bombus argillaceus (Scopoli, 1763) & + & Иванов и др., 2015 \\
\hline 75 & Шмель опоясанный - Bombus zonatus Smith, 1854 & + & Иванов и др., 2015 \\
\hline
\end{tabular}

(C) Н.С. Костенко, 2016

Труды Карадагской научной станции им. Т.И. Вяземского - природного заповедника РАН. - 2016. - Вып. 1 -67 - 
продолжение табл.2

\begin{tabular}{|c|c|c|c|c|}
\hline 76 & Кубиталия темная - Cubitalia morio Friese, 1911 & + & & Иванов и др., 2015 \\
\hline 77 & Габропода опоясанная - Habropoda zonatula Smith, 1854 & + & & Иванов и др., 2005 \\
\hline 78 & Пчела-плотник карликовая - Xylocopa iris (Christ, 1791) & + & & Иванов и др., 2015 \\
\hline 79 & Пчела-плотник обыкновенная - Xylocopa valga Gerstaecker, 1872 & + & + & Иванов и др., 2015 \\
\hline 80 & Пчела-плотник фиолетовая - Xylocopa violacea (Linnaeus, 1758) & + & & Иванов и др., 2015 \\
\hline \multicolumn{5}{|c|}{ Отряд двукрылые - Diptera } \\
\hline 81 & Меродон чернолапый - Merodon nigritarsis Rondani, 1845 & + & & Кустов, 2015 а \\
\hline 82 & Погоносома марокканская - Pogonosoma maroccanum (Fabricius, 1794) & + & & Кустов, 2015 б \\
\hline 83 & Сатанас гигантский - Satanas gigas (Eversmann, 1855) & + & & $\begin{array}{l}\text { Будашкин, личное } \\
\text { сообщение }\end{array}$ \\
\hline 84 & Хоботоголовник Таушера - Neorhynchocephalus tauscheri (Fisher, 1812) & + & & Кустов, 2015 в \\
\hline \multicolumn{5}{|c|}{ Тип хордовые - Chordata } \\
\hline \multicolumn{5}{|c|}{ Класс ланцетники - Leptocardii } \\
\hline \multicolumn{5}{|c|}{ Отряд ланцетникообразные - Amphioxiformes } \\
\hline 1 & Ланцетник европейский - Branchiostoma lanceolatum (Pallas, 1774) & + & & Гринцов, 2004 \\
\hline \multicolumn{5}{|c|}{ Класс лучеперые рыбы - Actinopterygii } \\
\hline \multicolumn{5}{|c|}{ Отряд осетрообразные - Acipenseriformes } \\
\hline 1 & Осетр русский - Acipenser gueldenstaedtii Brandt et Ratzeburg, 1833 & + & & $\begin{array}{l}\text { Костенко, Шаганов, } \\
2004\end{array}$ \\
\hline 2 & Шип - Acipenser nudiventris Lovetzky, 1828 & + & + & $\begin{array}{c}\text { Костенко, } \\
\text { Шаганов, } 2004\end{array}$ \\
\hline 3 & Севрюга - Acipenser stellatus Pallas, 1771 & + & & $\begin{array}{c}\text { Костенко, } \\
\text { Шаганов, } 2004\end{array}$ \\
\hline 4 & Белуга - Huso huso (Linnaeus, 1758) & + & + & $\begin{array}{c}\text { Костенко, Шаганов, } \\
2004 \\
\end{array}$ \\
\hline \multicolumn{5}{|c|}{ Отряд лососеобразные - Salmoniformes } \\
\hline 5 & Кумжа - Salmo labrax Pallas, 1814 & + & + & $\begin{array}{c}\text { Костенко, Шаганов, } \\
2004 \\
\end{array}$ \\
\hline \multicolumn{5}{|c|}{ Отряд колюшкообразные - Gasterosteiformes } \\
\hline 6 & Морской конек - Hipросатрus hippocampus (Linnaeus, 1758) & + & & $\begin{array}{l}\text { Костенко, Шаганов, } \\
2004\end{array}$ \\
\hline 7 & Морская игла длиннорылая - Syngnathus typhle Linnaeus, 1758 & + & & $\begin{array}{c}\text { Костенко, } \\
\text { Шаганов, } 2004\end{array}$ \\
\hline 8 & Морская игла толсторылая - Syngnathus variegatus Pallas, 1814 & + & & $\begin{array}{c}\text { Костенко, } \\
\text { Шаганов, } 2004 \\
\end{array}$ \\
\hline \multicolumn{5}{|c|}{ Отряд окунеобразные - Perciformes } \\
\hline 9 & Морской петух желтый - Chelidonichthys lucerna Linnaeus, 1758 & + & & $\begin{array}{c}\text { Костенко, } \\
\text { Шаганов, } 2004\end{array}$ \\
\hline 10 & Пуголовка звездчатая - Benthophilus stellatus (Sauvage, 1874) & + & & $\begin{array}{c}\text { Костенко, } \\
\text { Шаганов, 2004 }\end{array}$ \\
\hline 11 & Зеленый губан - Labrus viridis Linnaeus, 1758 & + & & $\begin{array}{l}\text { Костенко, Ярыш, } \\
2005 \\
\end{array}$ \\
\hline \multicolumn{5}{|c|}{ Класс земноводные - Amphibia } \\
\hline \multicolumn{5}{|c|}{ Отряд бесхвостые земноводные - Anura } \\
\hline 1 & Чесночница Палласа - Pelobates vespertinus (Pallas, 1771) & + & & $\begin{array}{l}\text { Котенко, Кукушкин, } \\
2010\end{array}$ \\
\hline 2 & Квакша восточная - Hyla orientalis Bedriaga, 1890 & + & & $\begin{array}{l}\text { Котенко, Кукушкин, } \\
2010\end{array}$ \\
\hline \multicolumn{5}{|c|}{ Класс пресмыкающиеся - Reptilia } \\
\hline \multicolumn{5}{|c|}{ Отряд ящерицы - Sauria } \\
\hline 1 & $\begin{array}{l}\text { Геккон средиземноморский - Mediodactylus kotschyi (Steindachner, } \\
\text { 1870) }\end{array}$ & + & & $\begin{array}{l}\text { Котенко, Кукушкин, } \\
2010\end{array}$ \\
\hline 2 & Желтопузик безногий - Pseudopus apodus (Pallas, 1775) & + & & Щербак, 1994 \\
\hline \multicolumn{5}{|c|}{ Отряд змеи - Serpentes } \\
\hline 3 & Полоз желтобрюхий - Dolichophis caspius (Gmelin, 1789) & + & & $\begin{array}{l}\text { Котенко, Кукушкин, } \\
2010\end{array}$ \\
\hline 4 & Полоз леопардовый - Zamenis situla (Linnaeus, 1758) & + & & $\begin{array}{c}\text { Котенко, Кукушкин, } \\
2010 \\
\end{array}$ \\
\hline
\end{tabular}


продолюсение табл.2

\begin{tabular}{|c|c|c|c|c|}
\hline \multicolumn{5}{|c|}{ Класс птицы - Aves } \\
\hline \multicolumn{5}{|c|}{ Отряд гагарообразные - Gaviiformes } \\
\hline 1 & Чернозобая гагара - Gavia arctica (Linnaeus, 1758) & & + & $\begin{array}{l}\text { Бескаравайный, } \\
2011\end{array}$ \\
\hline \multicolumn{5}{|c|}{ Отряд веслоногие - Pelecaniformes } \\
\hline 2 & Пеликан розовый - Pelecanus onocrotalus Linnaeus, 1758 & + & + & Бескаравайный, 2011 \\
\hline 3 & $\begin{array}{l}\text { Баклан хохлатый средиземноморский - Phalacrocorax aristotelis } \\
\text { desmarestii (Payraudeau, 1826) (гнездится) }\end{array}$ & + & + & $\begin{array}{l}\text { Бескаравайный, } \\
\text { 2011, } 2016\end{array}$ \\
\hline 4 & Баклан малый - Phalacrocorax pygmaeus (Pallas, 1773) & + & + & $\begin{array}{l}\text { Бескаравайный, } \\
\text { 2011, } 2016\end{array}$ \\
\hline \multicolumn{5}{|c|}{ Отряд аистообразные - Ciconiiformes } \\
\hline 5 & Цапля египетская - Bubulcus ibis (Linnaeus, 1758) & & + & $\begin{array}{l}\text { Бескаравайный, } \\
2012,2015\end{array}$ \\
\hline 6 & Цапля желтая - Ardeola ralloides (Scopoli, 1769) & + & & $\begin{array}{l}\text { Бескаравайный, } \\
\text { 2011, } 2016\end{array}$ \\
\hline 7 & $\begin{array}{l}\text { Каравайка - Plegadis falcinellus (Linnaeus, 1766) (К территории } \\
\text { заповедника не приурочена) }\end{array}$ & + & + & Бескаравайный, 2011 \\
\hline 8 & Аист черный - Ciconia nigra (Linnaeus, 1758) & + & + & $\begin{array}{l}\text { Бескаравайный, } \\
\text { 2011, } 2016\end{array}$ \\
\hline \multicolumn{5}{|c|}{ Отряд гусеобразные - Anseriformes } \\
\hline 9 & $\begin{array}{l}\text { Казарка краснозобая - Rufibrenta ruficollis (Pallas, 1769) (К территории } \\
\text { заповедника не приурочена) }\end{array}$ & + & + & $\begin{array}{l}\text { Бескаравайный, } \\
2011,2016\end{array}$ \\
\hline 10 & $\begin{array}{l}\text { Гусь серый - Anser anser (Linnaeus, 1758) (К территории заповедника } \\
\text { не приурочен) }\end{array}$ & + & & $\begin{array}{l}\text { Бескаравайный, } \\
\text { 2011, } 2016\end{array}$ \\
\hline 11 & Огарь - Tadorna ferruginea (Pallas, 1764) & + & & $\begin{array}{l}\text { Бескаравайный,2011, } \\
2016 \\
\end{array}$ \\
\hline 12 & Утка серая - Anas strepera Linnaeus, 1758 & + & & $\begin{array}{l}\text { Бескаравайный, } \\
\text { 2011, } 2016\end{array}$ \\
\hline 13 & Крохаль длинноносый - Mergus serrator Linnaeus, 1758 & + & & $\begin{array}{l}\text { Бескаравайный, } \\
\text { 2011, } 2016\end{array}$ \\
\hline \multicolumn{5}{|c|}{ Отряд соколообразные - Falconiformes } \\
\hline 14 & Скопа - Pandion haliaetus (Linnaeus, 1758) & + & + & $\begin{array}{l}\text { Бескаравайный, } \\
\text { 2011, } 2016\end{array}$ \\
\hline 15 & $\begin{array}{l}\text { Лунь степной - Circus macrourus (S.G. Gmelin, 1771) (К территории } \\
\text { заповедника не приурочен) }\end{array}$ & + & + & $\begin{array}{l}\text { Бескаравайный, } \\
2014,2015\end{array}$ \\
\hline 16 & Лунь луговой - Circus pygargus (Linnaeus, 1758) & + & & $\begin{array}{l}\text { Бескаравайный, } \\
2011,2015\end{array}$ \\
\hline 17 & Курганник - Buteo rufinus (Cretzschmar, 1827) (гнездится) & + & + & $\begin{array}{l}\text { Бескаравайный, } \\
2011,2016 \\
\end{array}$ \\
\hline 18 & Змееяд - Circaetus gallicus (Gmelin, 1788) (гнездится - ?) & + & + & $\begin{array}{l}\text { Бескаравайный, } \\
\text { 2011, } 2016\end{array}$ \\
\hline 19 & $\begin{array}{l}\text { Малый подорлик - Aquila pomarina C.L. Brechm, } 1831 \text { (К территории } \\
\text { заповедника не приурочен) }\end{array}$ & & + & $\begin{array}{l}\text { Бескаравайный, } \\
\text { 2013, } 2015\end{array}$ \\
\hline 20 & $\begin{array}{l}\text { Большой подорлик - Aquila clanga Pallas, } 1881 \text { (К территории } \\
\text { заповедника не приурочен) }\end{array}$ & & + & $\begin{array}{l}\text { Бескаравайный, } \\
2011\end{array}$ \\
\hline 21 & Могильник - Aquila heliaca Savigny, 1809 & + & + & $\begin{array}{l}\text { Бескаравайный, } \\
2011\end{array}$ \\
\hline 22 & $\begin{array}{l}\text { Беркут - Aquila chrysaetos (Linnaeus, 1758) (К территории заповедника } \\
\text { не приурочен) }\end{array}$ & + & + & $\begin{array}{l}\text { Бескаравайный, } \\
2011 \\
\end{array}$ \\
\hline 23 & $\begin{array}{l}\text { Орлан-белохвост Haliaeetus albicilla (Linnaeus, 1758) (К территории } \\
\text { заповедника не приурочен) }\end{array}$ & + & + & $\begin{array}{c}\text { Бескаравайный, } \\
2011 \\
\end{array}$ \\
\hline 24 & $\begin{array}{l}\text { Стервятник - Neophron percnopterus (Linnaeus, 1758) (К территории } \\
\text { заповедника не приурочен) }\end{array}$ & + & + & $\begin{array}{l}\text { Бескаравайный, } \\
2011\end{array}$ \\
\hline 25 & Гриф черный - Aegypius monachus (Linnaeus, 1766) & + & + & $\begin{array}{c}\text { Бескаравайный, } \\
\text { 2011, } 2016\end{array}$ \\
\hline 26 & Сип белоголовый - Gyps fulvus (Hablizl, 1783) (гнездится) & + & + & $\begin{array}{l}\text { Бескаравайный, } \\
\text { 2011, } 2016\end{array}$ \\
\hline 27 & Балобан - Falco cherrug Gray, 1834 (гнездится) & + & + & $\begin{array}{c}\text { Бескаравайный, } \\
\text { 2011, } 2016 \\
\end{array}$ \\
\hline
\end{tabular}


продолжение табл.2

\begin{tabular}{|c|c|c|c|c|}
\hline 28 & Сапсан - Falco peregrinus brookei Sharpe, 1873 (гнездится) & + & + & $\begin{array}{c}\text { Бескаравайный, } \\
2011,2016\end{array}$ \\
\hline \multicolumn{5}{|c|}{ Отряд журавлеобразные - Gruiformes } \\
\hline 29 & Красавка - Anthropoides virgo (Linnaeus, 1758) & + & + & $\begin{array}{l}\text { Бескаравайный, } \\
2011\end{array}$ \\
\hline 30 & Коростель - Crex crex (Linnaeus, 1758) & + & & $\begin{array}{l}\text { Бескаравайный, } \\
2011,2016\end{array}$ \\
\hline 31 & Дрофа - Otis tarda Linnaeus, 1758 & + & + & $\begin{array}{l}\text { Бескаравайный, } \\
2011\end{array}$ \\
\hline \multicolumn{5}{|c|}{ Отряд ржанкообразные - Charadriiformes } \\
\hline 32 & Авдотка - Burchinus oedicnemus (Linnaeus, 1758) & + & + & $\begin{array}{l}\text { Бескаравайный, } \\
2011\end{array}$ \\
\hline 33 & Ходулочник - Himantopus himantopus (Linnaeus, 1758) & + & + & $\begin{array}{l}\text { Бескаравайный, } \\
2011\end{array}$ \\
\hline 34 & $\begin{array}{l}\text { Шилоклювка - Recuvirostra avosetta (Linnaeus, 1758) (К территории } \\
\text { заповедника не приурочена) }\end{array}$ & + & + & $\begin{array}{l}\text { Бескаравайный, } \\
2011\end{array}$ \\
\hline 35 & Кулик-сорока - Haematopus ostralegus longipes Linnaeus, 1758 & + & + & $\begin{array}{l}\text { Бескаравайный, } \\
2011\end{array}$ \\
\hline 36 & Перевозчик - Actitis hypoleucos (Linnaeus, 1758) & + & & $\begin{array}{l}\text { Бескаравайный, } \\
2011,2016\end{array}$ \\
\hline 37 & Чернозобик - Calidris alpina (Linnaeus, 1758) & & + & $\begin{array}{l}\text { Бескаравайный, } \\
2011\end{array}$ \\
\hline 38 & $\begin{array}{l}\text { Кроншнеп большой - Numenius arcuata (Linnaeus, 1758) (К территории } \\
\text { заповедника не приурочен) }\end{array}$ & + & + & $\begin{array}{l}\text { Бескаравайный, } \\
2011\end{array}$ \\
\hline 39 & $\begin{array}{l}\text { Веретенник большой - Limosa limosa (Linnaeus, 1758) (К территории } \\
\text { заповедника не приурочен) }\end{array}$ & + & & $\begin{array}{l}\text { Бескаравайный, } \\
2011\end{array}$ \\
\hline 40 & Хохотун черноголовый - Larus ichthyaetus Pallas, 1773 & + & + & $\begin{array}{c}\text { Бескаравайный, } \\
2011,2016 \\
\end{array}$ \\
\hline 41 & $\begin{array}{l}\text { Чеграва - Hydropogne caspia (Pallas, 1770) (К территории заповедника } \\
\text { не приурочен) }\end{array}$ & + & + & $\begin{array}{l}\text { Бескаравайный, } \\
2011\end{array}$ \\
\hline 42 & $\begin{array}{l}\text { Крачка малая - Sterna albifrons Pallas, } 1764 \text { (К территории заповедника } \\
\text { не приурочен) }\end{array}$ & + & + & $\begin{array}{c}\text { Бескаравайный, } \\
2011,2016\end{array}$ \\
\hline \multicolumn{5}{|c|}{ Отряд голубеобразные - Columbiformes } \\
\hline 43 & Клинтух - Columba oenas Linnaeus, 1758 & + & & $\begin{array}{l}\text { Бескаравайный, } \\
2011\end{array}$ \\
\hline 44 & Голубь сизый - Columba livia Gmelin, 1789 (гнездится) & + & & $\begin{array}{c}\text { Бескаравайный, } \\
2011,2016\end{array}$ \\
\hline \multicolumn{5}{|c|}{ Отряд совообразные - Strigifolia } \\
\hline 45 & Филин - Виво bubo (Linnaeus, 1758) & + & + & $\begin{array}{c}\text { Бескаравайный, } \\
2011\end{array}$ \\
\hline 46 & Сова болотная - Asio flammeus (Pontoppidan, 1758) & + & & $\begin{array}{l}\text { Бескаравайный, } \\
2011\end{array}$ \\
\hline \multicolumn{5}{|c|}{ Отряд ракшеобразные - Coraciiformes } \\
\hline 47 & Сизоворонка - Coracias garrulus Linnaeus, 1758 & + & & $\begin{array}{c}\text { Бескаравайный, } \\
\text { 2011, } 2016\end{array}$ \\
\hline 48 & Зимородок обыкновенный - Alcedo atthis (Linnaeus, 1758) & + & & $\begin{array}{c}\text { Бескаравайный, } \\
\text { 2011, } 2016\end{array}$ \\
\hline \multicolumn{5}{|c|}{ Отряд воробьинообразные - Passeriformes } \\
\hline 49 & Сорокопут красноголовый - Lanius senator Linnaeus, 1758 & + & & $\begin{array}{l}\text { Бескаравайный, } \\
2011\end{array}$ \\
\hline 50 & Сорокопут серый - Lanius excubitor Linnaeus, 1758 & + & + & $\begin{array}{l}\text { Бескаравайный, } \\
2011\end{array}$ \\
\hline 51 & Скворец розовый - Sturnus roseus (Linnaeus, 1758) & + & & $\begin{array}{c}\text { Бескаравайный, } \\
\text { 2011, } 2016\end{array}$ \\
\hline 52 & Камышевка-барсучок - Acrocephalus schoenobaenus (Linnaeus, 1758) & + & & $\begin{array}{c}\text { Бескаравайный, } \\
2011 \\
\end{array}$ \\
\hline 53 & Королек желтоголовый - Regulus regulus (Linnaeus, 1758) & + & & $\begin{array}{c}\text { Бескаравайный, } \\
\text { 2011, } 2016\end{array}$ \\
\hline 54 & Королек красноголовый - Regulus ignicapillus (Temminck, 1820) & + & & $\begin{array}{c}\text { Бескаравайный, } \\
2011\end{array}$ \\
\hline
\end{tabular}


продолжение табл.2

\begin{tabular}{|c|c|c|c|c|}
\hline 55 & Каменка испанская - Oenanthe hispanica (Linnaeus, 1758) & + & & $\begin{array}{c}\text { Бескаравайный, } \\
\text { 2011, } 2016\end{array}$ \\
\hline 56 & Каменный дрозд пестрый - Monticola saxatilis (Linnaeus, 1776) & + & & $\begin{array}{l}\text { Бескаравайный, } \\
2011,2016\end{array}$ \\
\hline 57 & Овсянка черноголовая - Emberiza melanocephala Scopoli, 1769 & + & & $\begin{array}{l}\text { Бескаравайный, } \\
\text { 2011, } 2016\end{array}$ \\
\hline \multicolumn{5}{|c|}{ Класс млекопитающие - Mammalia } \\
\hline \multicolumn{5}{|c|}{ Отряд землеройкообразные - Soricomorpha } \\
\hline 1 & Белозубка белобрюхая - Crocidura leucodon Hermann, 1780 & + & & $\begin{array}{l}\text { Бескаравайный, } \\
\text { Шевченко, } 1989\end{array}$ \\
\hline 2 & Бурозубка малая - Sorex minutus Linnaeus, 1766 & + & & $\begin{array}{l}\text { Бескаравайный, } \\
\text { Шевченко, } 1989\end{array}$ \\
\hline \multicolumn{5}{|c|}{ Отряд рукокрылые - Vespertilioniformes } \\
\hline 3 & Подковонос большой - Rhinolophus ferrumequinum (Schreber, 1774) & + & + & $\begin{array}{l}\text { Годлевская и др., } \\
2009\end{array}$ \\
\hline 4 & Подковонос малый - Rhinolophus hipposideros (Bechstein, 1800) & + & + & $\begin{array}{l}\text { Годлевская и др., } \\
2009\end{array}$ \\
\hline 5 & Широкоушка европейская - Barbastella barbastellus (Schreber, 1774) & + & & $\begin{array}{l}\text { Бескаравайный, } \\
\text { Шевченко, } 1989\end{array}$ \\
\hline 6 & Кожан поздний - Eptesicus serotinus (Schreber, 1774) & + & & $\begin{array}{l}\text { Годлевская и др., } \\
2009\end{array}$ \\
\hline 7 & Нетопырь кожановидный - Hypsugo savii (Bonaparte, 1837) & + & & $\begin{array}{l}\text { Годлевская и др., } \\
2009\end{array}$ \\
\hline 8 & Длиннокрыл обыкновенный - Miniopterus schreibersi (Kuhl, 1817) & + & + & $\begin{array}{l}\text { Годлевская и др., } \\
2009\end{array}$ \\
\hline 9 & Ночница остроухая - Myotis blythii (Tomes, 1857) & + & + & $\begin{array}{c}\text { Годлевская и др., } \\
2009\end{array}$ \\
\hline 10 & Ночница трехцветная - Myotis emarginatus (Geoffroy, 1806) & + & + & $\begin{array}{c}\text { Годлевская и др., } \\
2009\end{array}$ \\
\hline 11 & Ночница усатая - Myotis mystacinus (Kuchl, 1817) & + & & $\begin{array}{l}\text { Бескаравайный, } \\
\text { Шевченко, } 1989\end{array}$ \\
\hline 12 & Вечерница рыжая - Nyctalus noctula (Schreber, 1774) & + & & Кукушкин, 2011 \\
\hline 13 & Нетопырь средиземноморский - Pipistrellus kuhlii (Kuchl, 1817) & + & & $\begin{array}{l}\text { Бескаравайный, } \\
\text { Шевченко, } 1989\end{array}$ \\
\hline 14 & Нетопырь лесной - Pipistrellus nathusii (Keyserling et Blasius, 1839) & + & & Кукушкин, 2011 \\
\hline 15 & Нетопырь-карлик - Pipistrellus pipistrellus (Schreber, 1774) & + & & $\begin{array}{l}\text { Бескаравайный, } \\
\text { Шевченко, } 1989\end{array}$ \\
\hline 16 & Нетопырь-пигмей - Pipistrellus pygmaeus (Leach, 1825) & + & & Кукушкин, 2011 \\
\hline 17 & Кожан двухцветный - Vespertilio murinus Linnaeus, 1758 & + & & Кукушкин, 2011 \\
\hline \multicolumn{5}{|c|}{ Отряд грызуны - Muriformes } \\
\hline 18 & Суслик малый - Spermophilus pygmaeus (Pallas, 1779) & + & & $\begin{array}{l}\text { Бескаравайный, } \\
\text { Шевченко, } 1989\end{array}$ \\
\hline 19 & Тушканчик большой - Allactaga major (Kerr, 1792) & + & & $\begin{array}{l}\text { Бескаравайный, } \\
\text { Шевченко, } 1989\end{array}$ \\
\hline 20 & Слепушонка обыкновенная - Ellobius talpinus (Pallas, 1770) & + & & $\begin{array}{l}\text { Бескаравайный, } \\
\text { Шевченко, } 1989\end{array}$ \\
\hline \multicolumn{5}{|c|}{ Отряд хищные - Carvinova } \\
\hline 21 & Хорь степной - Mustela eversmanni Lesson, 1827 & + & & $\begin{array}{l}\text { Бескаравайный, } \\
\text { Шевченко, } 1989\end{array}$ \\
\hline 22 & Барсук - Meles meles Linnaeus, 1758 & + & & $\begin{array}{l}\text { Бескаравайный, } \\
\text { Шевченко, } 1989\end{array}$ \\
\hline \multicolumn{5}{|c|}{ Отряд китообразные - Balaeniformes } \\
\hline 23 & Дельфин-белобочка - Delphinus delphis Linnaeus, 1758 & + & & $\begin{array}{l}\text { Бескаравайный, } \\
\text { Шевченко, } 1989\end{array}$ \\
\hline 24 & Афалина - Tursiops truncatus (Montagu, 1821) & + & + & $\begin{array}{l}\text { Бескаравайный, } \\
\text { Шевченко, } 1989\end{array}$ \\
\hline 25 & $\begin{array}{l}\text { Морская свинья - Phocoena phocoena (Linnaeus, 1758) (=Phocoena } \\
\text { phocoena relicta Abel, 1905) }\end{array}$ & + & + & $\begin{array}{l}\text { Бескаравайный, } \\
\text { Шевченко, } 1989\end{array}$ \\
\hline
\end{tabular}

Примечания к таблице: кэ - крымский эндемик; эч - эндемик Черного моря.

(C) Н.С. Костенко, 2016

Труды Карадагской научной станции им. Т.И. Вяземского - природного заповедника РАН. - 2016. - Вып. 1 
Фотоизображения животных, внесенных в Красную книгу Республики Крым, Красную книгу Российской Федерации представлены на рисунках 4-6.

Карадагский природный заповедник является центром биоразнообразия в Крыму, одной из приоритетных территорий для сохранения флоры и фауны. Здесь представлены естественные биоценозы, уникальные по составу растительных и животных сообществ. Поэтому заповедник является настоящей жемчужиной Восточного южнобережья Крыма и своеобразным рефугиумом элементов средиземноморской фауны в Крыму (Иванов и др., 2004). Количество видов животных Карадага, внесенных КК РК по отношению к общему числу краснокнижных крымских видов по отдельным систематическим группам колеблется в широких пределах. Из 12 видов моллюсков, внесенных в КК РК, 6 (50 \%) встречаются на Карадаге, причем один из них - эндемик Черного моря (табл. 2).

Тип членистоногие включает несколько классов животных. Из 17 видов ракообразных, внесенных в КК РК, 6 видов (24 \%) встречается на Карадаге. Из 4 видов паукообразных, значащихся в КК РК, на Карадаге представлены 2 (50\%). Причем один из них - ранее встречавшийся в заповеднике скорпион крымский (Ястребцов, 1994). Кандидат биологических наук Е.В. Гордеева (личное сообщение) отмечала скорпиона на биостанции в 1996 году.

Наиболее обширным по количеству краснокнижных видов является класс насекомые. В КК РК внесено 196 видов насекомых, из них - 84 встречается на Карадаге, что составляет 42,8 \% от краснокнижных крымских видов. В число карадагских видов входят 6 крымских эндемиков. Наибольшую ценность представляют комплексы степных фитофагов, среди которых бабочки, жуки, прямокрылые, двукрылые и перепончатокрылые насекомые (Будашкин и др., 2013). Первое место по числу видов занимает отряд перепончатокрылые - 28 из 56, внесенных в КК РК, что составляет $50 \%$ крымской фауны краснокнижных видов. Перепончатокрылые представлены комплексом фитофагов и насекомых-опылителей. На втором месте - отряд чешуекрылые, насчитывающий на Карадаге 23 из 50 видов КК РК, что составляет 46 \%. Бабочки представлены целым рядом уникальных степных видов (Будашкин и др., 2013). Среди бражников на Карадаге отмечен редчайший вид бражник карликовый и редкий в восточном Крыму бражник хорватский, который встречается в местах с хорошо сохранившейся степной растительностью. На участках с разнотравной растительностью обитает уникальный степной вид махаон. На третьем месте - отряд жесткокрылые - 14 видов из 45 (31\%). Небольшим количеством краснокнижных видов на Карадаге характеризуются отряды стрекоз - 3 вида из 8 (37,5\%), таракановые - 3 (100\%), прямокрылые 5 из 7 (71 \%), эмбии - 1 вид (100\%), сетчатокрылые - 5 видов из 6 (83\%), двукрылые - 4 вида из $15(26 \%)$. Среди приведенного разнообразия много оригинальных насекомых, приуроченных к небольшим участкам петрофитной степи (Будашкин и др., 2013). Примером такого насекомого может служить бабочник колыванский.

В типе хордовые в КК РК внесен один представитель класса ланцетники, обнаруженный на Карадаге директором Карадагской биологической станции доктором биологических наук К.А. Виноградовым в конце 1940-х годов. В акватории Черного моря у Карадага к настоящему времени известно 115 видов рыб, из них 11 внесено в КК РК, что составляет 78 \% от общего числа краснокнижных видов (14).

В Крыму обитает 5 видов амфибий и 14 видов рептилий (Котенко, Кукушкин, 2013). На Карадаге класс земноводных включает соответственно 3 вида из 3 (100\%), класс пресмыкающихся - 3 вида из 10 (30 \%), значащихся в КК РК. Среди земноводных на Карадаге встречается редкий для Крымского полуострова вид - чесночница Палласа (Котенко, Кукушкин, 2013). Из пресмыкающихся наиболее редким видом является средиземноморский геккон, до настоящего времени выявленный только в Карадагском заповеднике (Котенко, Кукушкин, 2013). Желтопузик наблюдался на Карадаге в 1946 г., с 1980 г. не встречался (Щербак, 1989, 1994).

Заповедник играет важную роль в сохранении орнитологического разнообразия региона. Уникальное сочетание целого ряда природных факторов явилось причиной высокого орнитологического разнообразия. Среди них: широкий диапазон элементов рельефа, разнообразие наземной растительности (от степной до широколиственных лесов), наличие аквально-территориального экотопа (море-суша), мозаичность микроклиматических условий. Данный район является пересечением нескольких основных путей миграции птиц 
(Бескаравайный и др., 2013). На Карадаге зарегистрировано 238 видов птиц из 277, известных в Восточном Крыму (Бескаравайный и др., 2013). В заповеднике встречается 52 вида птиц - 76 \% от числа видов, внесенных в КК РК (68 видов). Среди них имеются как гнездящиеся (табл. 2), так и виды, которые, как правило, непосредственно с территорией заповедника не связаны. Важна роль заповедника в охране крымской популяции хохлатого баклана (вторая по численности гнездовая группировка в Крыму), балобана и сапсана (Бескаравайный и др., 2013). Из крупных птиц на Карадаге более полувека назад был характерен огромный ночной хищник филин, обитавший в районе хребта Сюрю-Кая (Пузанов, 1959).

В Крыму зарегистрировано 62 вида млекопитающих (Дулицкий и др., 2013), более половины из них - 34 вида внесены в КК РК. Список млекопитающих Карадагского природного заповедника, по данным О.В. Кукушкина, насчитывает 44 вида. На Карадаге известно 25 краснокнижных видов млекопитающих (74 \% от общего числа внесенных в КК РК видов). Среди «насекомоядных» в КК РФ внесено 2 вида, из них белозубка белобрюхая, по данным О.В. Кукушкина, последний раз была зарегистрирована в 1993 г.

На Карадаге наиболее многочисленным является отряд рукокрылые - 15 краснокнижных видов из 21, $71 \%$ от числа известных в Крыму. Рукокрылые - одна из наиболее уязвимых групп млекопитающих, что обусловлено низкими темпами их размножения, сокращением количества пригодных убежищ и кормовой базы (Дулицкий и др., 2013). Длиннокрыл числится в фаунистическом списке условно, этот вид был уничтожен в Крыму «деятелями образования» еще в первой половине XX века (Дулицкий и др., 2013). Последняя регистрация длиннокрыла на Карадаге была отмечена в 1947 году. В КК РК он рассматривается как вероятно исчезнувший вид. Для ночницы усатой последняя регистрация колоний, по данным О.В. Кукушкина, была отмечена в 1982 году, единичные детекторные регистрации - в 2001 году. Единично отмечена на Карадаге широкоушка европейская - в 1984 и 2003 гг., вечерница рыжая (2004 и 2005 гг.). Нетопырь-пигмей включен в список по данным детекторных регистраций 2004 года. Нетопырь лесной последний раз отмечался на Карадаге в 1925 году, нетопырь кожановидный - в 1990 году, кожан двухцветный - в 1988 г. (данные предоставлены О.В. Кукушкиным).

В фауне Карадага раньше встречались такие грызуны как суслик малый. В 1924-1925 гг. К.К. Флеров насчитывал на степном участке Лобового хребта до 70 сусликов. По данным экспедиции Львовского университета, работавшей на Карадаге в 1957 г., под Святой горой обитало 3 колонии сусликов (Пузанов, 1959). Последняя регистрация суслика на Карадаге была отмечена в 1963 г. В настоящее время на территории заповедника суслик отсутствует (Бескаравайный, Шевченко, 1989). Тушканчик большой был большой редкостью, по свидетельству И.И. Пузанова. В 1924-1925 гг. К.К. Флеров насчитывал на степном участке Лобового хребта около 10 тушканчиков. Вид исчез к 1953 г. В настоящее время в заповеднике тушканчик отсутствует (Бескаравайный, Шевченко, 1989). Слепушонка обыкновенная - грызун, обитавший прежде на Карадаге. Заметим, что С.И. Огнев в 1915 г. считал слепушонка обычным видом на Карадаге, но уже в 1924-1925 гг. К.К. Флеров его уже не обнаружил (Пузанов, 1959). Не отмечена слепушонка на Карадаге и в последующие годы (Бескаравайный, Шевченко, 1989). Эти три краснокнижных вида внесены в список (табл. 2). Среди хищных на Карадаге раньше отмечался хорь степной, также внесенный в КК РК. Последняя достоверная регистрация хоря степного на Карадаге - до 1925 г. В более позднее время хорь степной в заповеднике не отмечен (Бескаравайный, Шевченко, 1989).

В акватории Черного моря у Карадага встречаются морские млекопитающие, которые представлены 3 видами китоообразных, внесенных в КК РК.

Анализ данных таблицы 2 показывает, что в КК РФ внесено 52 вида животных Карадагского заповедника, из них 7 насекомых, которые являются общими с КК РК. Тридцать четыре вида птиц, зарегистрированных на Карадаге, внесены в КК РФ. Семь видов млекопитающих, внесенных в КК РФ, являются общими со списком КК РК.

Как показал проведенный анализ, из 193 вида животных Карадага, внесенных в КК РК, ряд видов, к сожалению, уже не встречается на территории заповедника - в основном это представители класса пресмыкающихся (желтопузик), птиц (филин), млекопитающих (грызуны, рукокрылые, хищные), что свидетельствует о негативном влиянии ряда неблагоприятных факторов на сохранение популяций этих видов за период почти вековой истории их изучения. 


\section{Заключение}

Красные книги являются документами государственной значимости, «охранной грамотой» для дикой флоры и фауны. Сопоставление списков «краснокнижных» видов российского и регионального масштабов свидетельствует об особой значимости Карадагского природного заповедника в сохранении как региональной, так и российской флоры, и фауны. На территори Карадагского заповедника сосредоточено значительное количество «краснокнижных» видов: 147 растений, водорослей и грибов, что составляет 36,7 \% от представленных в КК РК и 193 вида животных из КК РК (52 \% от представленных в КК РК). Количество карадагских видов в КК РФ - 49 видов растений и 52 вида животных, что служит подтверждением особой важности их сохранения в пределах территоррии заповедника, где на небольшой площади в 20 кв. км сосредоточено высокое биологическое разнообразие. Красные книги на сегодня - это оружие в борьбе за охрану природы. Они - своеобразный «индикатор» нашего отношения к природе, показатель нашей гражданской совести и ответственности перед Родиной (Сосновский, 1987).

Благодарности. Автор приносит благодарность научным сотрудникам и ученому секретарю ФГБУН «Карадагская научная станция - природный заповедник РАН» кандидату биологических наук В.В. Фатерыге за критический просмотр списков растений, кандидату биологических наук, заведующему отделом изучения биоразнообразия и экологического мониторинга Ю.И. Будашкину за ценные замечания, кандидату биологических наук старшему научному сотруднику отдела М.М. Бескаравайному за критический просмотр списков птиц и ценные замечания по их гнездованию, кандидату биологических наук старшему научному сотруднику отдела А.В. Фатерыге за критический просмотр списков фауны.

\section{Список литературы}

1. Бескаравайный М.М. Аннотированный список птиц Карадагского природного заповедника // Научные записки природного заповедника «Мыс Мартьян». - 2011. - Вып. 2. - С. 259291.

2. Бескаравайный М.М. Птицы // Карадагский природный заповедник. Летопись природы. T. XXIX. 2012 г. - Карадаг. - 2013. - С. 128-137. Рукопись.

3. Бескаравайный М.М. Птицы // Карадагский природный заповедник. Летопись природы. Т. ХХХ. 2013 г. - Карадаг. - 2014. - С. 127-139. Рукопись.

4. Бескаравайный М.M. Некоторые итоги орнитологических исследований на юго-востоке Крыма в начале XXI века // 100 лет Карадагской научной станции / Сборник научных трудов / Ред. А.В. Гаевская, А.Л. Морозова. - Симферополь. - Н. Оріанда, 2015. - С. 355 360.

5. Бескаравайный М.М. Птицы Красной книги Крыма в заповедниках Азово-Черноморского побережья // Заповедники Крыма - 2016. Биологическое и ландшафтное разнообразие, охрана и управление / Тезисы VIII Международной научно-практической конференции, Симферополь, 28-30 апреля 2016 г. - Симферополь: ООО «Эльиньо», 2016. - С. 270-272.

6. Бескаравайный М.М., Андрющенко Ю.А., Костин С.Ю. Современное состояние и территориально-биотопическое распределение орнитофауны Восточного Крыма // Природа Восточного Крыма. Оценка биоразнообразия и разработка проекта локальной экологической сети / Отв. ред. д.б.н. С.П. Иванов. - К., 2013. - С. 61-66.

7. Бескаравайный М.M., Шевченко Л.С. // Природа Карадага / Бескаравайный М.M., Костенко Н.С., Миронова Л.П. и др. / Под. ред. А.Л. Морозова, А.А. Вронский. - Киев: Наукова думка, 1989. - С. 221-228.

8. Бровдій В.М., Воловник С.В. Левкомігус білосніжний // Червона книга України. Тваринний світ / Під ред. М.М. Щербака. - Київ: Видавництво «Українська енциклопедія імені М.П. Бажана», 1994. - С. 106. 
9. Будашкин Ю.И. Насекомые (чешуекрылые) // Природа Карадага / Под ред. А.Л. Морозовой, А.А. Вронского. - Киев: Наукова думка, 1989. - С. 177-194.

10. Будашкин Ю.И. Итоги двадцатилетнего стационарного изучения фауны чешуекрылых (Lepidoptera) Карадагского природного заповедника // Карадаг. История, геология, ботаника, зоология / Сборник научных трудов, посвященный 90-летию Карадагской научной станции им. Т.И. Вяземского и 25-летию Карадагского природного заповедника НАН Украины. Книга 1-я. - Симферополь: СОНАТ, 2004. - С. 323-366.

11. Будашкин Ю.И. Эублемма порядочная // Красная книга Республики Крым. Животные. Симферополь: ООО «ИТ «АРИАЛ», 2015 а. - С. 162.

12. Будашкин Ю.И. Совка розовая // Красная книга Республики Крым. Животные. Симферополь: ООО «ИТ «АРИАЛ», 2015 б. - С. 176.

13. Будашкин Ю.И. Совка мрачная // Красная книга Республики Крым. Животные. Симферополь: ООО «ИТ «АРИАЛ», 2015 в. - С. 178.

14. Будашкин Ю.И. Хвостатка вязовая // Красная книга Республики Крым. Животные. Симферополь: ООО «ИТ «АРИАЛ», 2015. - С. 187.

15. Будашкин Ю.И., Иванов С.П., Филатов М.А., Фатерыга А.В., Савчук В.В. Основные энтомологические комплексы и экологическая характеристика некоторых редких и охраняемых видов насекомых Восточного Крыма // Природа Восточного Крыма. Оценка биоразнообразия и разработка проекта локальной экологической сети / Отв. ред. д.б.н. С.П. Иванов. - К., 2013. - С. 46-54.

16. Войцехович А.О., Надєіна О.В., Кондратюк С.Я., Ходосовцев О.Є. Ілюстрований конспект лишайників та ліхенофільних грибів Карадазького природного заповідника // 100 лет Карадагской научной станции им. Т.И. Вяземского / Сборник научных трудов. Симферополь: Н. Оріанда, 2015. - С. 134-159.

17. Годлевская Е.В., Гхазали М.А., Постава Т. Современное состояние троглофильных видов рукокрылых (Mammalia, Chiroptera) Крыма // Вестник зоологии. - 2009. - Т. 43, вып. 3. - С. 253-265.

18. Горохов А.В. Сверчок византийский // Красная книга Республики Крым. Животные. Симферополь: ООО «ИТ «АРИАЛ». - 2015. - С. 84.

19. Горохов А.В. Дыбка степная // Красная книга Республики Крым. Животные. Симферополь: ООО «ИТ «АРИАЛ». - 2015 б. - С. 88.

20. Горохов А.В. Кобылка крестовая крымская // Красная книга Республики Крым. Животные. Симферополь: ООО «ИТ «АРИАЛ». - 2015 в. - С. 89.

21. Гринцов В.А. Тип Хордовые. Асцидии. Аппендикулярии. Головохордовые // Карадаг. Гидробиологические исследования / Сборник научных трудов, посвященный 90-летию Карадагской научной станции им. Т.И. Вяземского и 25-летию Карадагского природного заповедника НАН Украины. Книга 2-я. - Симферополь: СОНАТ, 2004. - С. 438-439.

22. Гринцов В.А., Мурина В.В., Киселева Г.А., Безвушко А.И. Отряд Десятиногие раки // Карадаг. Гидробиологические исследования / Сборник научных трудов, посвященный 90летию Карадагской научной станции им. Т.И. Вяземского и 25-летию Карадагского природного заповедника НАН Украины. Книга 2-я. - Симферополь: СОНАТ, 2004. - С. 378-383.

23. Дулицкий А.И., Годлевская Е.В., Чирний В.И., Зимнухов Р.А., Гольдин Е.Б., Товпинец Н.Н., Евстафьев И.Л. Материалы к структурированию локальной экосети Восточного Крыма на основании териофаунистических данных // Природа Восточного Крыма. Оценка биоразнообразия и разработка проекта локальной экологической сети / Отв. ред. д.б.н. С.П. Иванов. - Киев, 2013. - С. 67-74.

24. Захаренко О.В., Котенко А.Г. Мантіспа штирійська // Червона книга України. Тваринний світ / За ред. І.А. Акімова. - Київ: Глобалконсалтинг, 2009. - С. 137.

25. Срмоленко В.М. Емпуза смугаста // Червона книга України. Тваринний світ / Під ред. М.М. Щербака. - Київ: Видавництво «Українська енциклопедія імені М.П. Бажана», 1994 а. - C. 70 . 
26. Єрмоленко В.М. Ірис плямистокрилий // Червона книга України. Тваринний світ / Під ред. М.М. Щербака. - Київ: Видавництво «Українська енциклопедія імені М.П. Бажана», 1994 б. - C. 72.

27. Срмоленко В.М. Пилкохвіст Плігінського // Червона книга України. Тваринний світ / Під ред. М.М. Щербака. - Київ: видавництво «Українська енциклопедія імені М.П. Бажана», 1994 в. - С. 77.

28. Єрмоленко В.М. Ембія реліктова // Червона книга України. Тваринний світ / Під ред. М.М. Щербака. - Київ: видавництво «Українська енциклопедія імені М.П. Бажана», 1994. C. 81.

29. Срмоленко В.М., Котенко А.Г., Кукушкин О.В. Аскалаф строкатий // Червона Книга України. Тваринний світ / За ред. І.А. Акімова. - К.: Глобалконсалтинг, 2009. - С.135.

30. Ефетов К.А., Будашкин Ю.И. Бабочки Крыма: (Высшие разноусые чешуекрылые) / Справочник. - Симферополь: Таврия. $-1990 .-112$ с.

31. Загородняя Ю.А., Павловская Т.В., Морякова В.К. Подкласс Веслоногие // Карадаг. Гидробиологические исследования / Сборник научных трудов, посвященный 90-летию Карадагской научной станции им. Т.И. Вяземского и 25-летию Карадагского природного заповедника НАН Украины. Книга 2-я. - Симферополь: СОНАТ, 2004. - С. 364-367.

32. Иванов С.П., Амолин А.В., Фатерыга А.В. Складчатокрылые осы (Hymenoptera, Vespidae: Masarinae, Eumeninae) Карадагского природного заповедника и Восточной части Южного берега Крыма: видовой состав и структура биоразнообразия // Карадаг. История, геология, ботаника, зоология / Сборник научных трудов, посвященный 90-летию Карадагской научной станции им. Т.И. Вяземского и 25-летию Карадагского природного заповедника. Книга 1-я. - Симферополь: СОНАТ, 2004. - С. 307-322.

33. Иванов С.П., Будашкин Ю.И., Филатов М.А., Мосякин С.А. Опыт подготовки списков «краснокнижных» видов насекомых Крыма и предложения по включению некоторых крымских насекомых в Красную книгу Украины // Рідкісні та зникаючі види комах і концепції Червоної книги України: Матер. доп. наук. конф. (Київ, 29-31 березня 2004 р.) Київ. - 2005. - С. 40-48.

34. Иванов С.П., Фатерыга А.В., Филатов М.А. «Краснокнижные» виды ос и пчел Нymenoptera: Vespoidea, Apoidea) Карадагского природного заповедника и прилегающих территорий // 100 лет Карадагской научной станции им. Т.И. Вяземского / Сборник научных трудов. Симферополь: Н. Оріанда, 2015. - С. 296-308.

35. Иванов С.П., Филатов М.А., Фатерыга А.В. Пчелы-мегахидиды (Hymenoptera: Apoidea; Megachilidae) Карадагского природного заповедника, Отузской долины и Лисьей бухты // Карадаг - 2009 / Сборник научных трудов, посвященный 95-летию Карадагской научной станции и 30-летию Карадагского природного заповедника Национальной академии наук Украины. - Севастополь: ЭКОСИ-Гидрофизика, 2009. - С. 208-2014.

36. Каменских Л.Н., Миронова Л.П. Конспект флоры высших сосудистых растений Карадагского природного заповедника НАН Украины (Крым) // Карадаг. История, геология, ботаника, зоология / Сборник научных трудов, посвященный 90-летию Карадагской научной станции им. Т.И. Вяземского и 25-летию Карадагского природного заповедника. Книга 1-я. - Симферополь: СОНАТ, 2004. - С. 161-223.

37. Костенко Н.С. Картирование фитобентоса акватории Карадагского государственного заповедника АН УССР (Черное море) // Ботанический журнал. - 1988. - Т. 73, № 11. - С. 1590-1596.

38. Костенко Н.С., Евстигнеева И.К., Дикий Е.А. Водоросли-макрофиты // Карадаг. Гидробиологические исследования / Сборник научных трудов, посвященный 90-летию Карадагской научной станции им. Т.И. Вяземского и 25-летию Карадагского природного заповедника НАН Украины. Книга 2-я. - Симферополь: СОНАТ, 2004. - С. 275-307.

39. Костенко Н.С., Шаганов В.В. Рыбы // Карадаг. Гидробиологические исследования / Сборник научных трудов, посвященный 90 -летию Карадагской научной станции им. Т.И. Вяземского 
и 25-летию Карадагского природного заповедника НАН Украины. Книга 2-я. Симферополь: СОНАТ, 2004. - С. 440-453.

40. Костенко Н.С., Ярыш В.Л. О находке редкого вида рыб петропсаро (Labrus viridis Linnaeus, 1758) у берегов Феодосии // Морской экологический журнал. Отдельный выпуск. - 2005. № $1 .-$ C. 38 .

41. Котенко Т.И., Кукушкин О.В. Аннотированные списки земноводных и пресмыкающихся заповедников Крыма // Научные записки природного заповедника «Мыс Мартьян» - Ялта. 2010. - Вып. 1. - С. 225-261.

42. Котенко Т.И., Кукушкин О.В. Территории Восточного Крыма - объекты региональной экосети, важные для сохранения герпетофауны // Природа Восточного Крыма. Оценка биоразнообразия и разработка проекта локальной экологической сети / Отв. ред. д.б.н. С.П. Иванов. - Киев, 2013. - С. 55-60.

43. Красная книга Республики Крым. Растения, водоросли и грибы / Отв. ред. д.б.н., проф. А.В. Ена и к.б.н. А.В. Фатерыга. - Симферополь: ООО «ИТ АРИАЛ», 2015. - 480 с.

44. Красная книга Республики Крым. Животные / Отв. ред. д.б.н., проф. С.П. Иванов и к.б.н. А.В. Фатерыга. - Симферополь: ООО «ИТ АРИАЛ», 2015 а. - 440 с.

45. Красная книга Российской Федерации (растения и грибы) / Р.В. Камелин и др. (сост.). - М.: Товарищество научных изданий КМК, 2008. - 885 с.

46. Красная книга Российской Федерации (животные) / В.И. Данилов - Данильян и др. (ред.). М.: АСТ: Астрель, 2001. - 862 с.

47. Кривохатский В.А., Прокопов Г.А. Кривошпор западный // Красная книга Республики Крым. Животные. - Симферополь: ООО «ИТ «АРИАЛ». - 2015 а. - С. 139.

48. Кривохатский В.А., Прокопов Г.А. Невролеон сходный // Красная книга Республики Крым. Животные. - Симферополь: ООО «ИТ «АРИАЛ». - 2015 б. - С. 140.

49. Кривохатский В.А., Прокопов Г.А. Шпорник бэтийский // Красная книга Республики Крым. Животные. - Симферополь: ООО «ИТ «АРИАЛ». - 2015 в. - С. 141.

50. Кукушкин О.В. Рукокрылые (Chiroptera) // Карадагский природный заповедник. Летопись природы. Т. XXV. 2008 г. - Симферополь: Н. Оріанда. - 2010 а. - С. 277 - 280.

51. Кукушкин О.В. Млекопитающие, или звери // Карадаг заповедный: научно-популярные очерки - Симферополь: Н. Оріанда, 2011. - С. 142-150.

52. Кукушкин О.В. О закономерностях в распространении обыкновенной сольпуги (Arachnida, Solifugae, Galeodidae) на юге Украины // Самарская Лука: проблемы региональной и глобальной экологии. - 2013. - Т. 22, № 3. - С. 144-160.

53. Кустов С.Ю. Меродон чернолапый // Красная книга Республики Крым. Животные. Симферополь: ООО «ИТ «АРИАЛ». - 2015 а. - С. 258.

54. Кустов С.Ю. Погоносома марокканская // Красная книга Республики Крым. Животные. Симферополь: ООО «ИТ «АРИАЛ». - 2015 б. - С. 262.

55. Кустов С.Ю. Хоботоголовник Таушера // Красная книга Республики Крым. Животные. Симферополь: ООО «ИТ «АРИАЛ». - 2015 в. - С. 265.

56. Леонов С.В. Улитка крымская // Красная книга Республики Крым. Животные. Симферополь: ООО «ИТ «АРИАЛ». - 2015. - С. 49.

57. Мартынов В.В., Мосякин С.А. Жук-олень // Красная книга Республики Крым. Животные. Симферополь: ООО «ИТ «АРИАЛ». - 2015. - С. 110.

58. Мильчакова Н.А., Александров В.В., Бондарева Л.В., Панкеева Т.В., Чернышева Е.Б. / Под ред. Н.А.Мильчаковой // Морские охраняемые акватории Крыма. Научный справочник. Симферополь: Н. Оріанда, 2015. - 312 с.

59. Миронова Л.П., Костенко Н.С., Дідух Я.П., Онищенко В.А., Войцехович А.О. ПЗ Карадазький // Фіторізноманіття заповідників і національних природних парків України. Ч.1. Біосферні заповідники. Природні заповідники / Колектів авторів під ред. В.А. Онищенка і Т.Л. Андрієнко. - Київ: Фітосоціоцентр, 2012. - С. 170-197. 
60. Миронова Л.П., Фатерыга В.В. Флора Карадагского природного заповедника (сосудистые растения) // 100 лет Карадагской научной станции им. Т.И.Вяземского / Сборник научных трудов / Ред. А.В. Гаевская, А.Л. Морозова. - Симферополь: Н. Оріанда, 2015. - С. 160-204.

61. Мирошников А.И., Бартенев А.Ф. Усач большой дубовый // Красная книга Республики Крым. Животные. - Симферополь: ООО «ИТ «АРИАЛ». - 2015. - С. 121.

62. Мосякин С.А. Стафилин волосатый // Красная книга Республики Крым. Животные. Симферополь: ООО «ИТ «АРИАЛ». - 2015 а. - С. 106.

63. Мосякин С.А. Стафилин короткокрылый // Красная книга Республики Крым. Животные.Симферополь: ООО «ИТ «АРИАЛ». - 2015 б. - С. 107.

64. Мосякин С.А. Скрытоглав двуцветный // Красная книга Республики Крым. Животные. Симферополь: ООО «ИТ «АРИАЛ». - 2015 в. - С. 120.

65. Мосякин С.А., Пучков А.В. Жужелица шероховатая // Красная книга Республики Крым. Животные. - Симферополь: ООО «ИТ «АРИАЛ». - 2015. - С. 98.

66. Партика Л.Я., Нипорко С.О. Мохоподібні Карадазького природного заповідника // Карадаг 2009 / Сборник научных трудов, посвященный 95-летию Карадагской научной станции и 30летию Карадагского природного заповедника Национальной академии наук Украины / Ред. А.В. Гаевская, А.Л. Морозова. - Севастополь: ЭКОСИ-Гидрофизика, 2009. - С. 102-108.

67. Прокопов Г.А., Турбанов И.С. Усач-краснокрыл Ренивона // Красная книга Республики Крым. Животные. - Симферополь: ООО «ИТ «АРИАЛ». - 2015. - С. 127.

68. Пучков А.В. Карабидофауна // Карадагский природный заповедник. Летопись природы. Т. XX1. 2004 г. - Симферополь: СОНАТ. - 2006. - С. 175-176.

69. Пузанов И.И. Животный мир Карадага // Карадаг: научно-популярные очерки / А.Н. Смирнов, М.И. Котов, И.И. Пузанов, А.М. Дьяконов, Д.Л. Грищенко. - Киев: изд-во Академии наук Украинской ССР. - 1959. - С. 25-39.

70. Пучков А.В., Мосякин С.А. Красотел пахучий // Красная книга Республики Крым. Животные. - Симферополь: ООО «ИТ «АРИАЛ». - 2015. - С. 95.

71. Пушкар T.I., Срмоленко В.М. Боліварія короткокрила // Червона книга України. Тваринний світ / За ред. І.А. Акімова. - К.: Глобалконсалтинг, 2009. - С. 76.

72. Пушкар T.І., Назаренко В.Ю., Срмоленко В.М. Анадримадуза Ретовського // Червона книга України. Тваринний світ / За ред. І.А. Акімова. - К.: Глобалконсалтинг, 2009. - С. 83.

73. Ревков Н.К., Костенко Н.С., Киселева Г.А., Анистратенко В.В. Тип Моллюски Mollusca Cuvier, 1797 // Карадаг. Гидробиологические исследования / Сборник научных трудов, посвященный 90-летию Карадагской научной станции им. Т.И. Вяземского и 25-летию Карадагского природного заповедника НАН Украины. Книга 2-я. - Симферополь: СОНАТ, 2004. - С. 399-435.

74. Рыфф Л.Э. Конрингия булавовидная. Красная Книга Республики Крым. Растения, водоросли и грибы. - Симферополь: ООО «ИТ «АРИАЛ». - 2015. - С. 186.

75. Саркина И.С., Миронова Л.П. Макроскопические грибы основных типов растительных сообществ Карадагского природного заповедника // Карадаг - 2009: Сборник научных трудов, посвященный 95-летию Карадагской научной станции и 30-летию Карадагского природного заповедника Национальной академии наук Украины / Ред. А.В. Гаевская, А.Л. Морозова. - Севастополь: ЭКОСИ-Гидрофизика, 2009. - С. 78-101.

76. Саркина И.С., Миронова Л.П. Аннотированный список базидиальных и сумчатых макромицетов Карадагского природного заповедника // Научные записки природного заповедника «Мыс Мартьян». - 2015 а. - Вып. 6. - С. 297-326.

77. Саркина И.С., Миронова Л.П. Роль лесокультуры в формировании микобиоты Карадагского природного заповедника (макромицеты) // 100 лет Карадагской научной станции им. Т.И. Вяземского / Сборник научных трудов. - Симферополь: Н. Оріанда. -2015 б. С. 241-253.

78. Сосновский И.П. Редкие и исчезающие животные: По страницам Красной книги СССР. М.: Металлургия, 1987. - 367 с. 
79. Турбанов И.С. Брахицерус грязный // Красная книга Республики Крым. Животные. Симферополь: ООО «ИТ «АРИАЛ». - 2015. - С. 132.

80. Фатерыга А.В. Стефанус зубценосный // Красная книга Республики Крым. Животные. Симферополь: «ООО «АРИАЛ». - 2015 а. - С. 201.

81. Фатерыга А.В. Гедихрум зеленый // Красная книга Республики Крым. Животные. Симферополь: «ООО «АРИАЛ». - 2015 б. - С. 202.

82. Фатерыга А.В. Стильбум зеленоватый // Красная книга Республики Крым. Животные. Симферополь: «ООО «АРИАЛ». - 2015 в. - С. 204.

83. Фатерыга В.В. Селитрянка Шобера // Красная книга Республики Крым. Растения, водоросли и грибы. - Симферополь: ООО «ИТ «АРИАЛ», 2015. - С. 334.

84. Фатерыга В.В., Фатерыга А.В. О произрастании Epipactis krymmontana (Orchidaceae) в Карадагском заповеднике // Заповедники Крыма. Биологическое и ландшафтное разнообразие, охрана и управление / Материалы VIII Международной научно-практической конференции (Симферополь, 28-30 апреля 2016 г.). - Симферополь, 2016. - С. 256-258.

85. Червона книга України. Тваринний світ / Під ред. М.М. Щербака. - Київ: Видавництво «Українська енциклопедія імені М.П.Бажана», 1994. - 460 с.

86. Червона книга України. Тваринний світ / За ред. І.А. Акімова. - К.: Глобалконсалтинг, 2009. $-600 \mathrm{c}$.

87. Шоренко К.И. История изучения и кадастровый список видов роющих ос (Hymenoptera: Ampulicidae, Sphecidae, Crabronidae) Крымского полуострова // 100 лет Карадагской научной станции им. Т.И. Вяземского / Сборник научных трудов. - Симферополь: Н. Оріанда. - 2015. - С. 309-354.

88. Щербак Н.Н. Земноводные и пресмыкающиеся // Природа Карадага / Под ред. А.Л. Морозовой и А.А. Вронского. - Киев: Наукова думка, 1989. - С. 194-197.

89. Щербак М.М. Жовтопуз / Червона книга України. Тваринний світ // Під ред. М.М. Щербака. - Київ: Вид-во «Українська енциклопедія» імені М.П. Бажана, 1994. - С. 295.

90. Ястребцов А.В. Сольпуга звичайна // Червона книга України. Тваринний світ / Під ред. М.М. Щербака. - Київ: Вид-во «Українська енциклопедія» імені М.П. Бажана, 1994 а. - С. 59.

91. Ястребцов А.В. Скорпион кримський // Червона книга України. Тваринний світ / Під ред. М.М. Щербака. - Київ: Вид-во «Українська енциклопедія» імені М.П. Бажана, 1994 б. - С. 58

92. Fateryga A.V., Kreutz C.A.J., Fateryga V.V., Efimov P.G. Epipactis crymmontana (Orchidaceae) A new species endemic to the Crimean Mountains and notes on the related taxa in the Crimea and bordering Russian Caucasus // Phytotaxa. - 2014. - Vol. 172, N 1. - P. 22-30.

Поступила 13 июля 2016 г. В окончательном виде 26 августа 2016 г.

\section{RARITET SPECIES OF FLORA AND FAUNA AT THE KARADAG NATURE RESERVE N.S. Kostenko \\ T.I.Vyazemsky Karadag Scientific Station - Nature Reserve of the RAS, Feodosia, Russian Federation, karadag1914@mail.ru}

The article is about rare species of flora and fauna at the Karadag Nature Reserve (Crimea). These species are included into the Red Data Book of the Republic of Crimea (2015) and Red Data Book of the Russian Federation (2001, 2008). 147 species of plants, algae and fungi are included into the Red Data Book of the Republic of Crimea. 49 species of plants and fungi are included into the Red Data Book of the Russian Federation. 193 species of fauna are included into the Red Data Book of Crimea. 52 species of fauna are included into the Red Data Book of the Russian Federation. 19 species of vascular plants are the Crimean endemics.

Key words: Red Data Book of the Republic of Crimea, Red Data Book of the Russian Federation, plants, algae and fungi, fauna, raritet species, endemic, Karadag Nature Reserve.

(C) Н.С. Костенко, 2016

Труды Карадагской научной станции им. Т.И. Вяземского - природного заповедника РАН. - 2016. - Вып. 1 


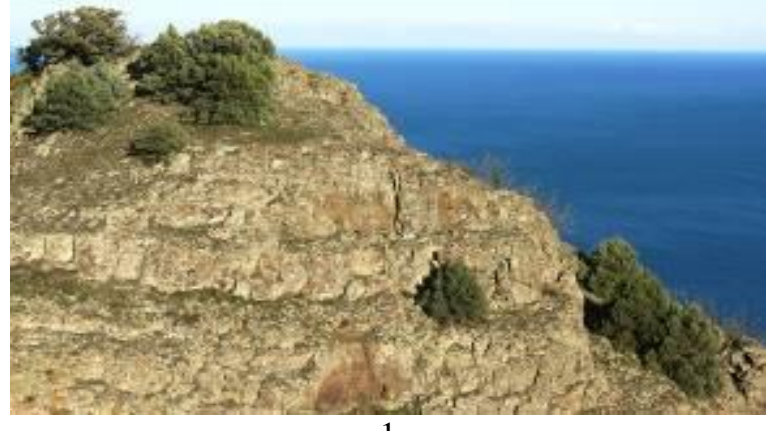

1

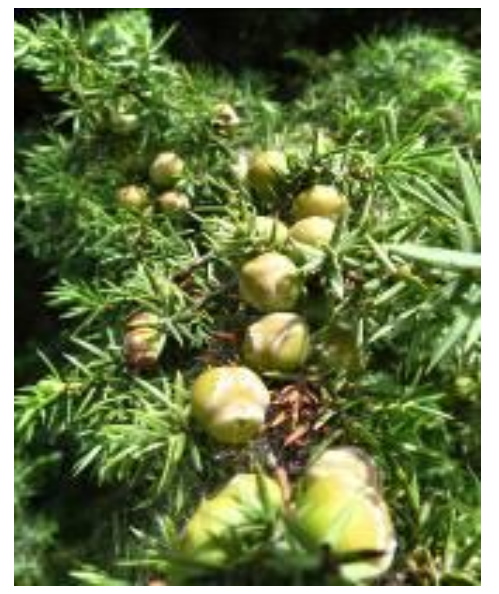

3
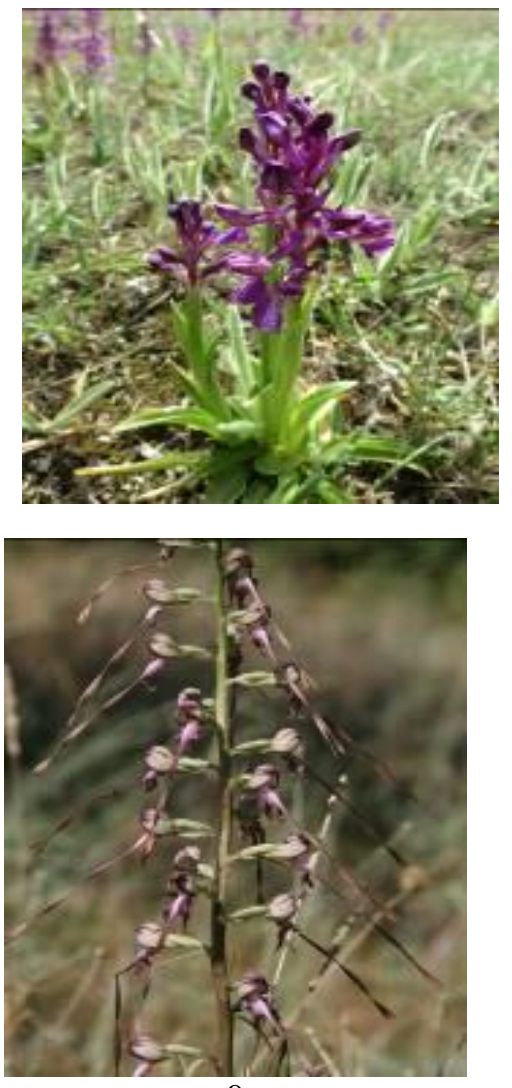

9

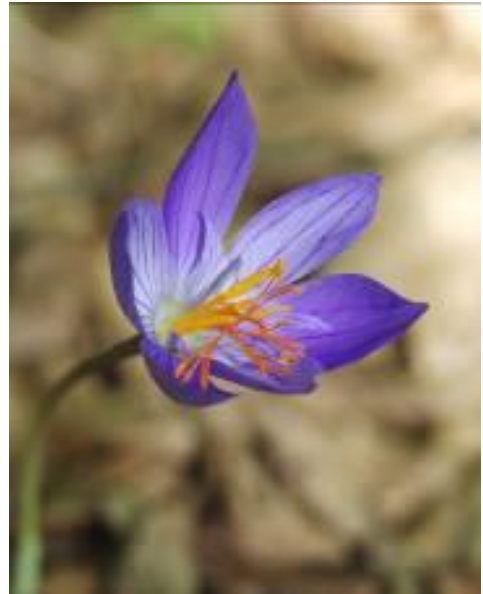

4

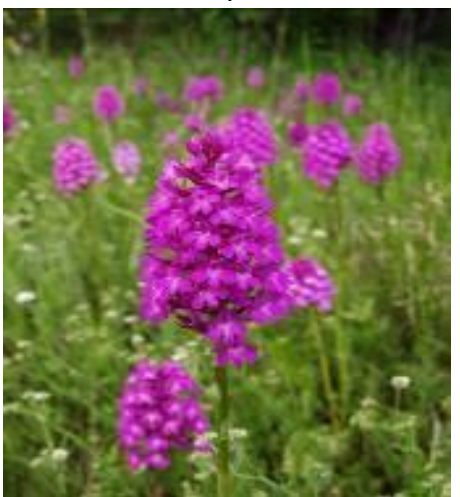

7

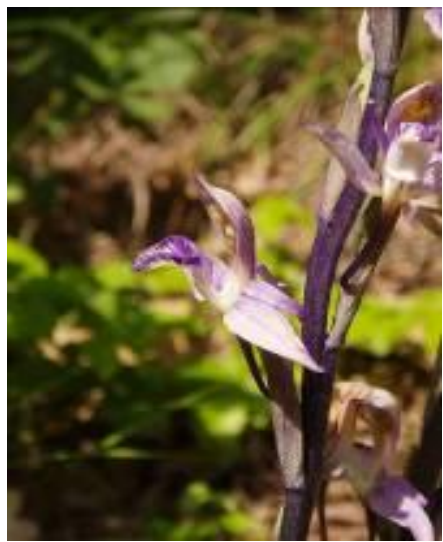

10

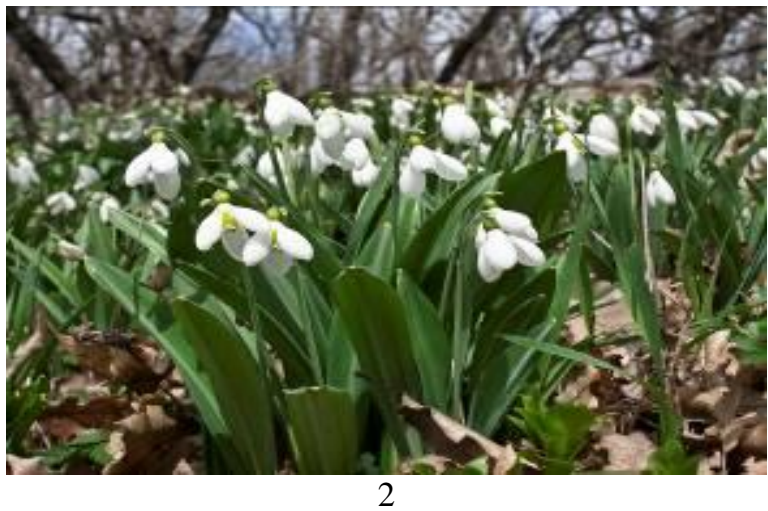

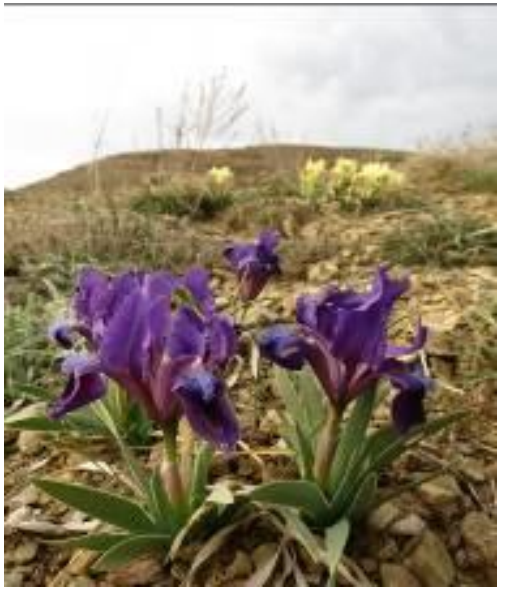

5
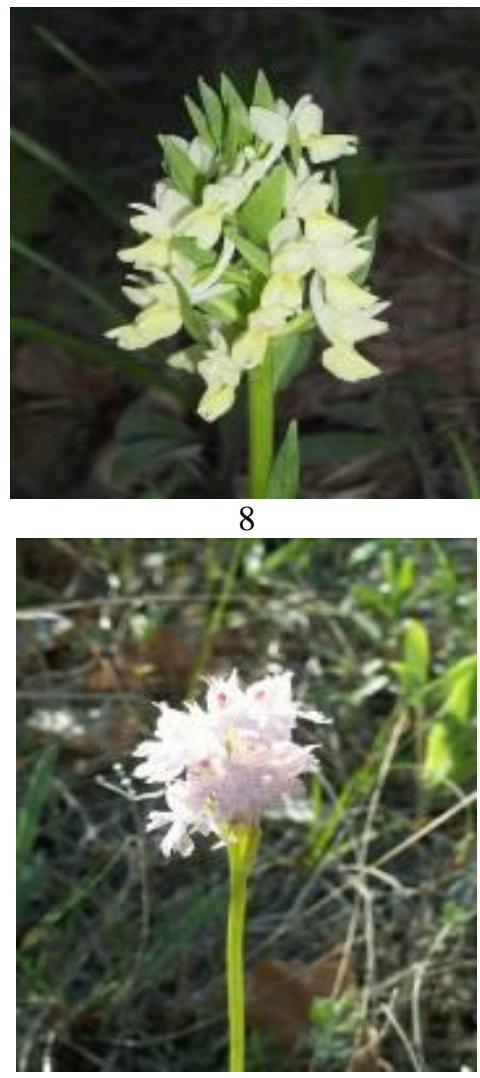

11

Рис. 1. Объекты растительного мира Карадагского природного заповедника: 1 - можжевельник высокий, 2 подснежник складчатый, 3 - можжевельник дельтоводный, 4 - крокус прекрасный, 5 - ирис низкий, 6 - анакамптис кавказский, 7 - анакамптис пирамидальный, 8 - пальчатокоренник римский, 9 - ремнелепестник козий, 10 лимодорум недоразвитый, 11 - неотинея трехзубчатая

Фото: Л.В. Знаменская $(2,4,7,8,9,10)$, Р.С. Кветков $(1,3,5,6,11)$. 


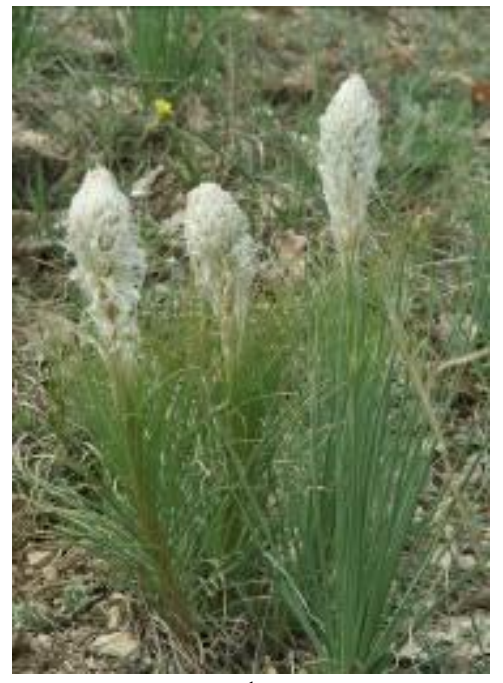

1

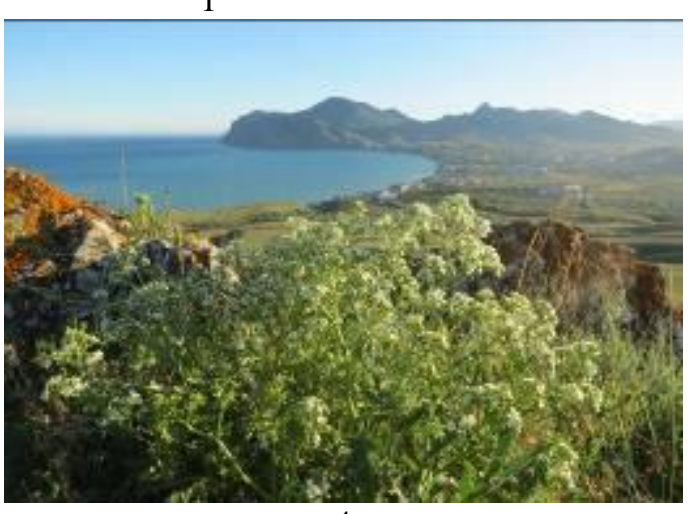

4
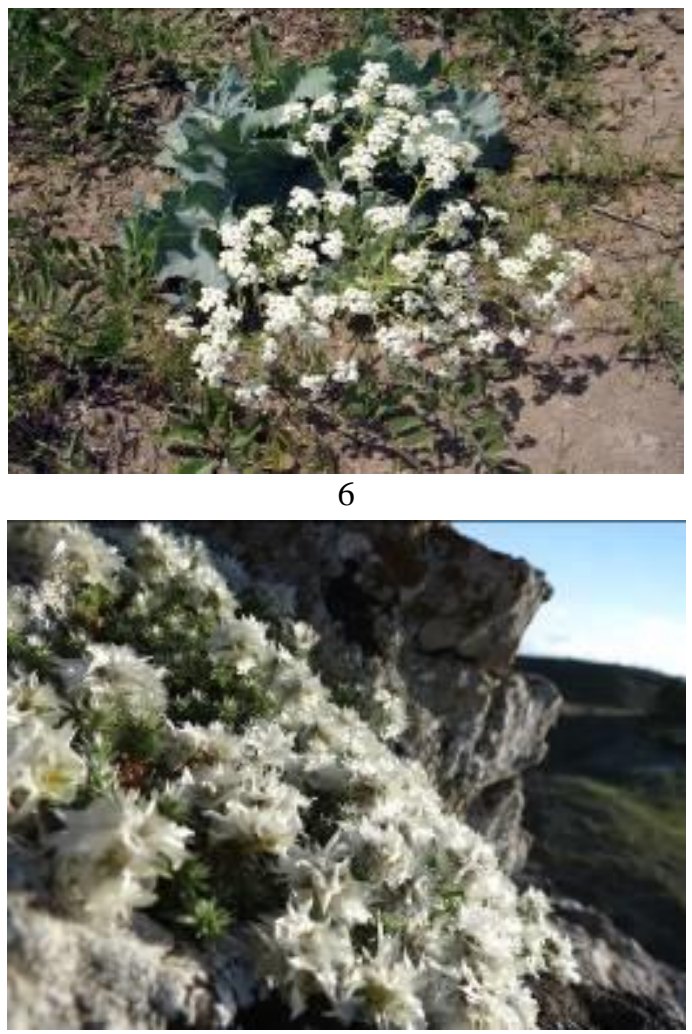

8

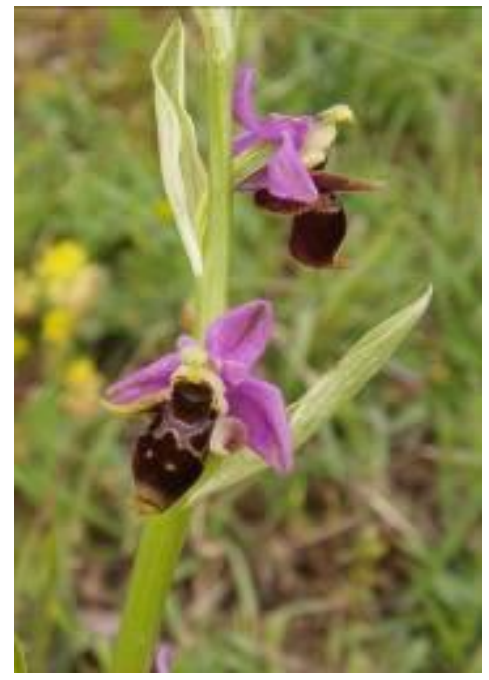

2

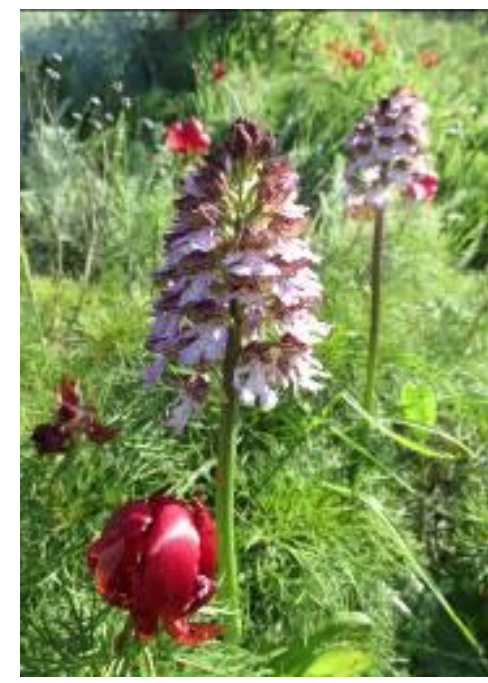

3
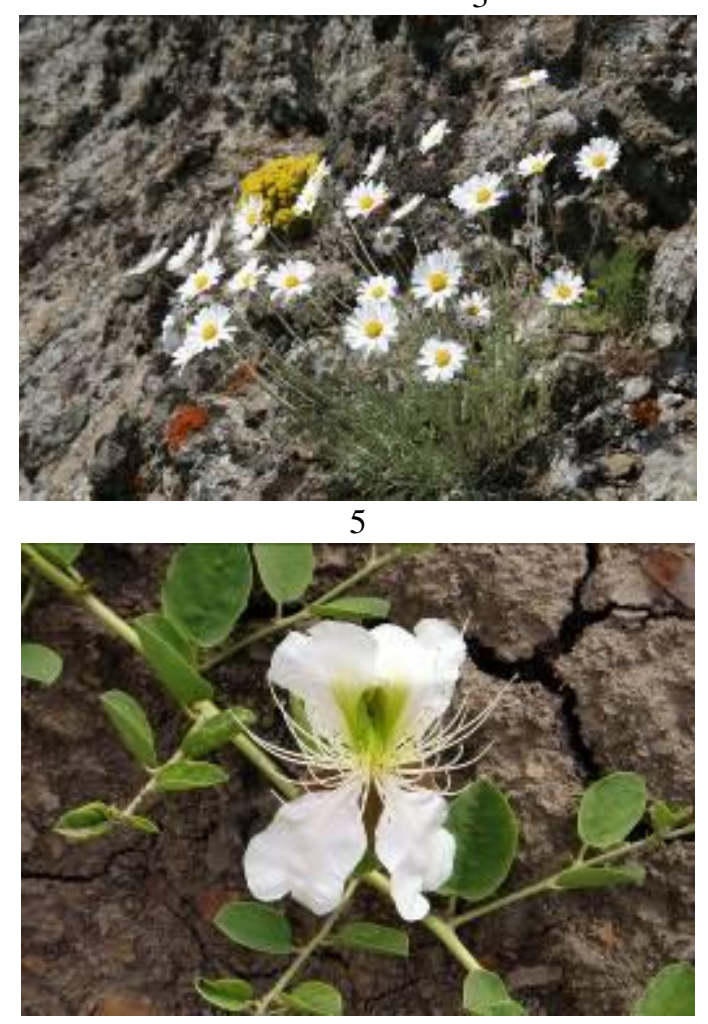

7

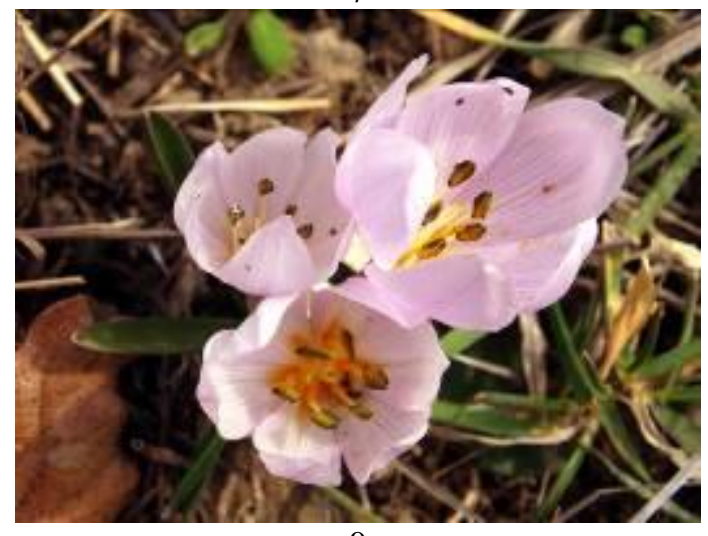

9

Рис. 2. Объекты растительного мира Карадагского природного заповедника: 1 - асфоделина крымская, 2 - офрис оводоносная, 3 - ятрышник пурпурный, 4 - катран коктебельский, 5 - пупавка бесплодная, 6 - катран приморский, 7 - каперы травянистые, 8 - приноготовник головчатый, 9 - безвременник анкарский Фото: Л.В. Знаменская $(2,5,6,7,9)$, Р.С. Кветков $(1,3,4,8)$. 


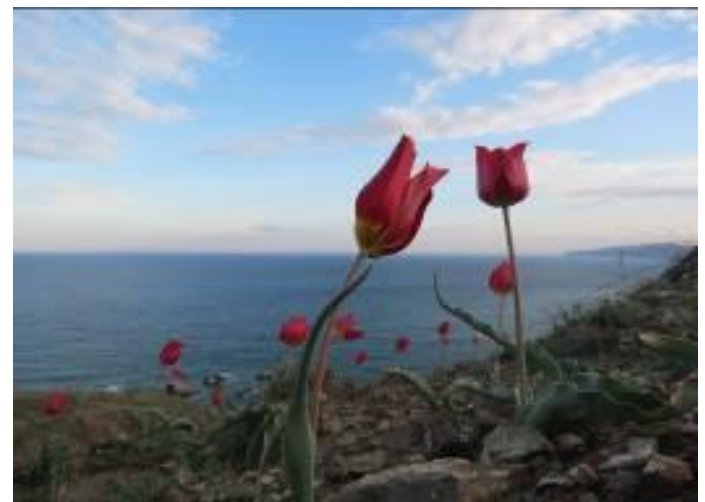

1

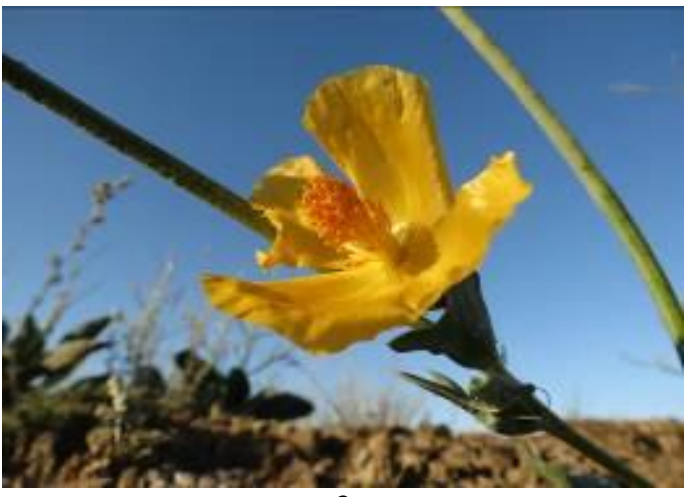

3



5

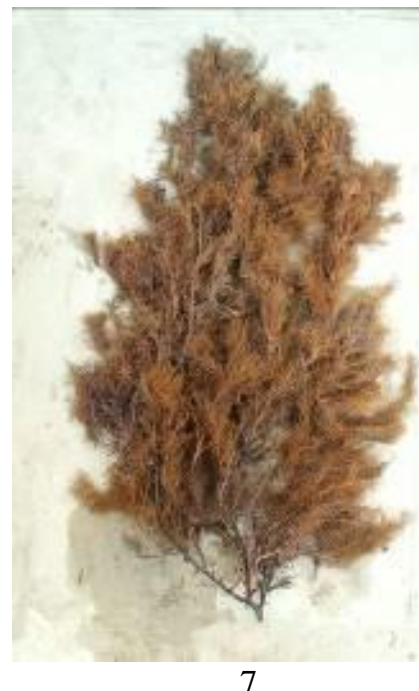

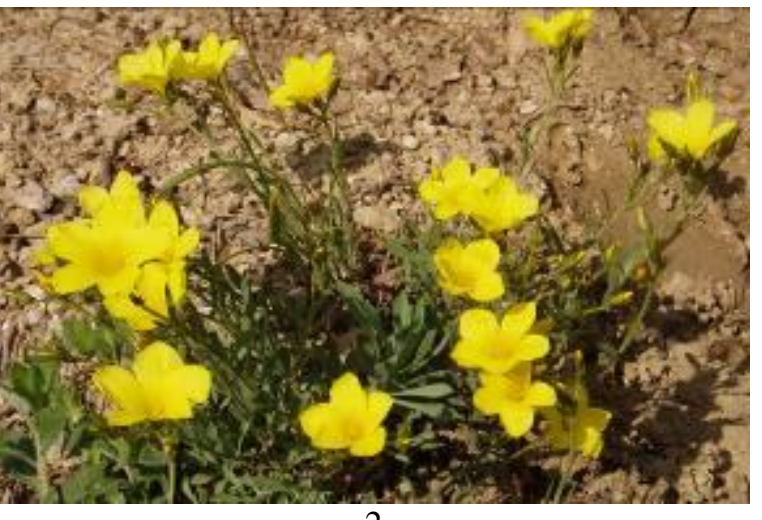

2

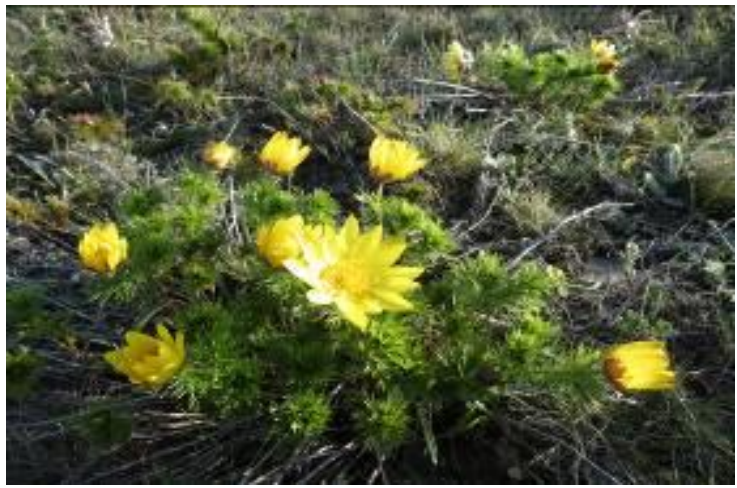

4
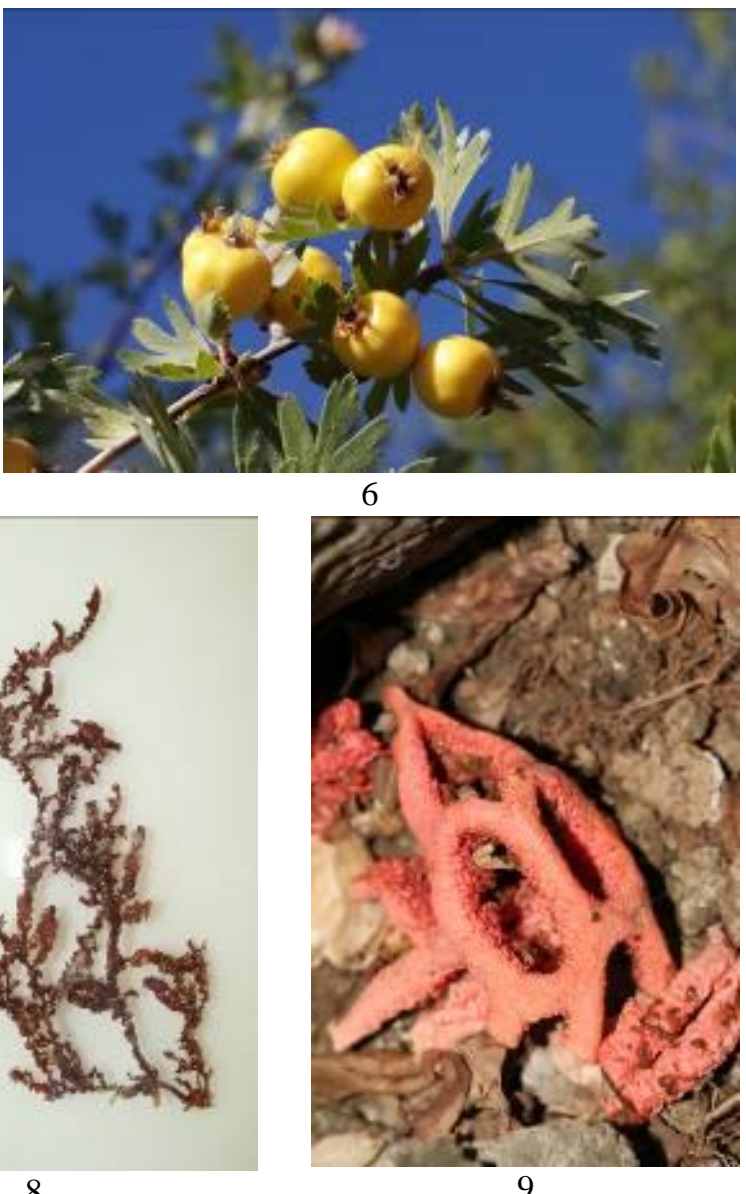

Рис. 3. Объекты растительного мира Карадагского природного заповедника: 1 - тюльпан душистый, 2 - лен Палласа, 3 - мачок желтый, 4 - адонис весенний, 5 - прострел крымский, 6 - боярышник Поярковой, 7 - цистозира бородатая, 8 - филлофора курчавая, 9 - решеточник красный

Фото: Л.В. Знаменская $(2,5,6,9)$, Р.С. Кветков $(1,3,4,7,8)$ 


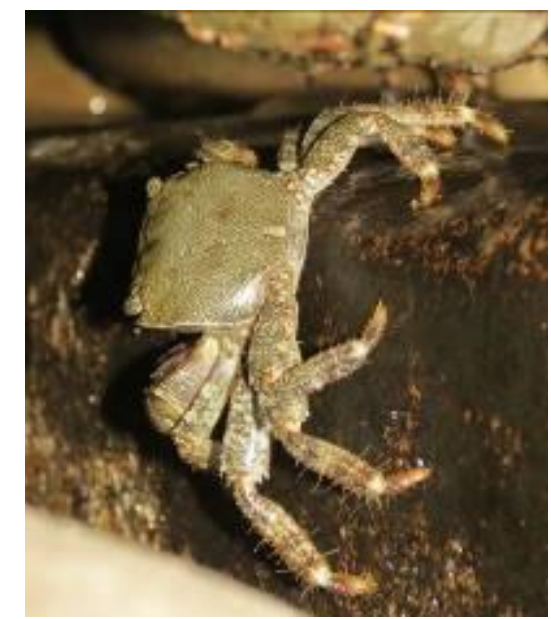

1

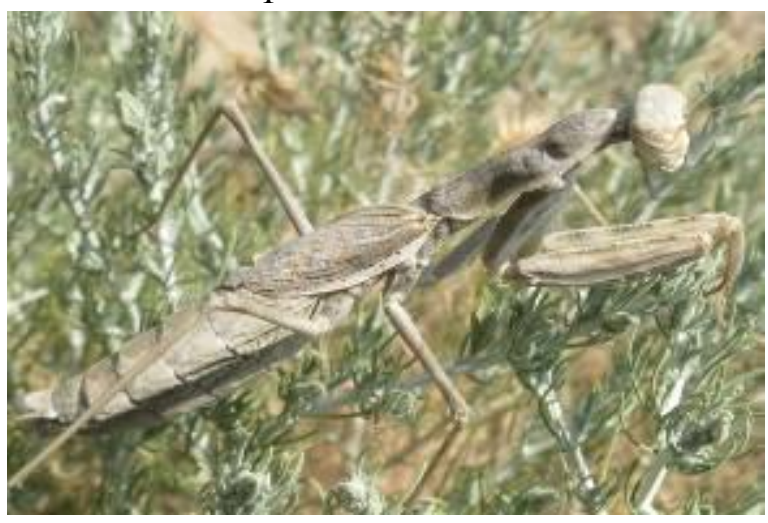

4

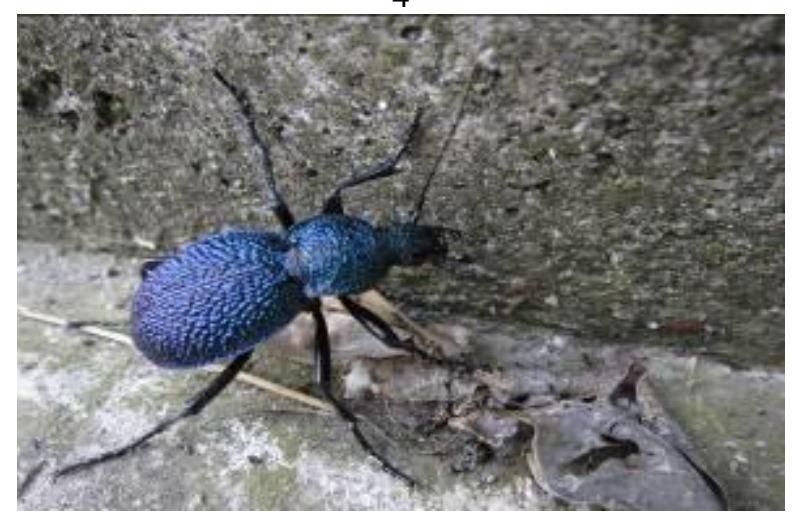

6

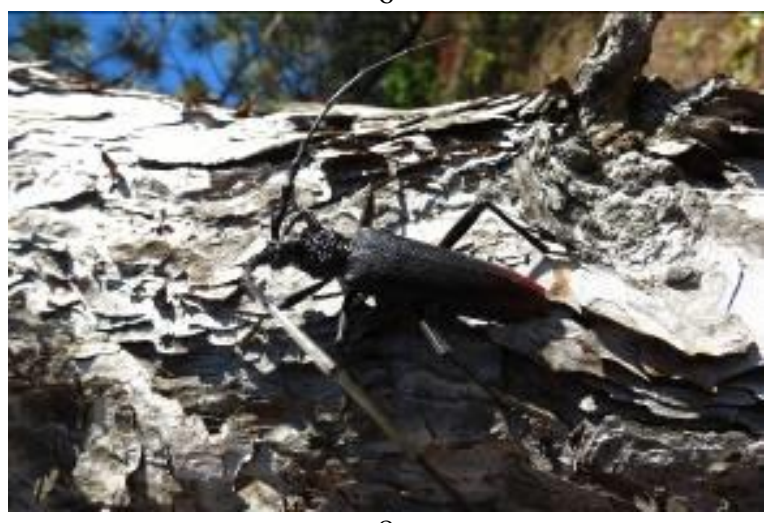

8

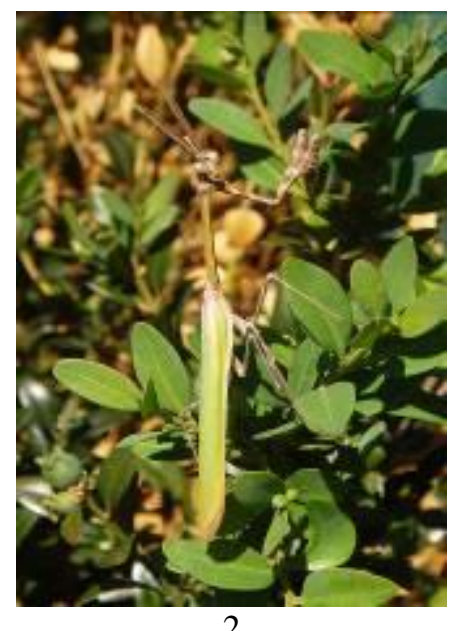

2

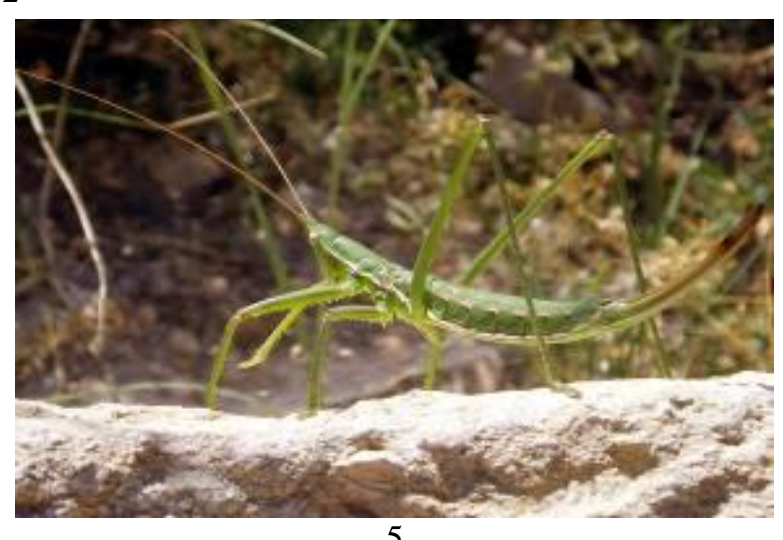

5

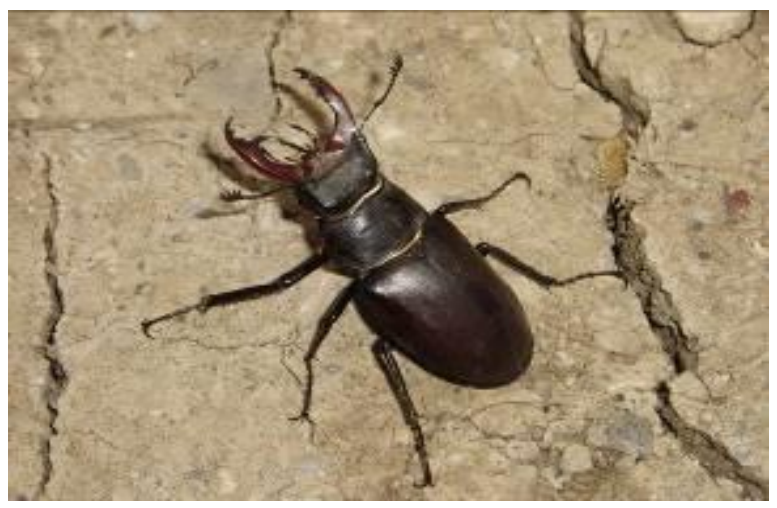

7

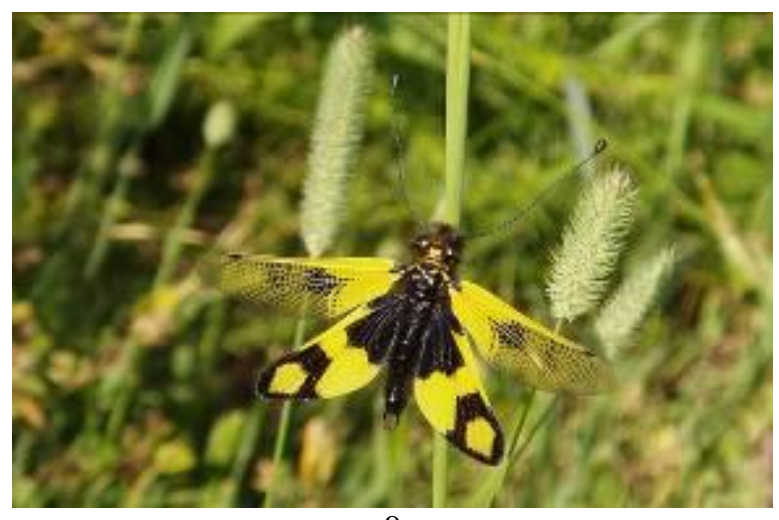

9

Рис. 4. Объекты животного мира Карадагского природного заповедника: 1 - краб мраморный, 2 - эмпуза полосатая, 3 - сольпуга обыкновенная, 4 - боливария короткокрылая, 5 - дыбка степная, 6 - жужелица шероховатая крымская, 7 - жук-олень, 8 - усач большой дубовый, 9 - бабочник колыванский

Фото: Л.В. Знаменская $(2,3,5,7,9)$, Р.С. Кветков $(1,4,6,8)$. 


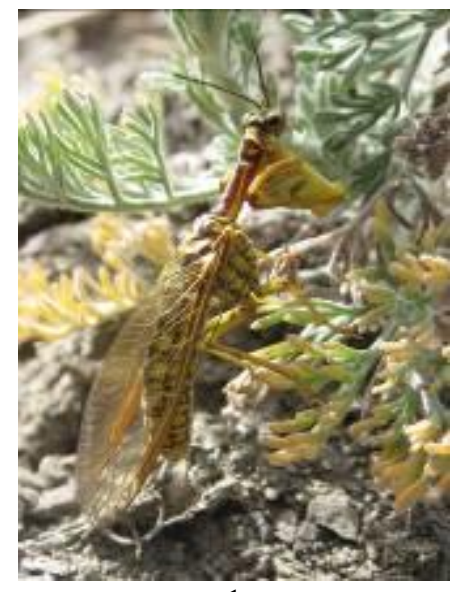

1

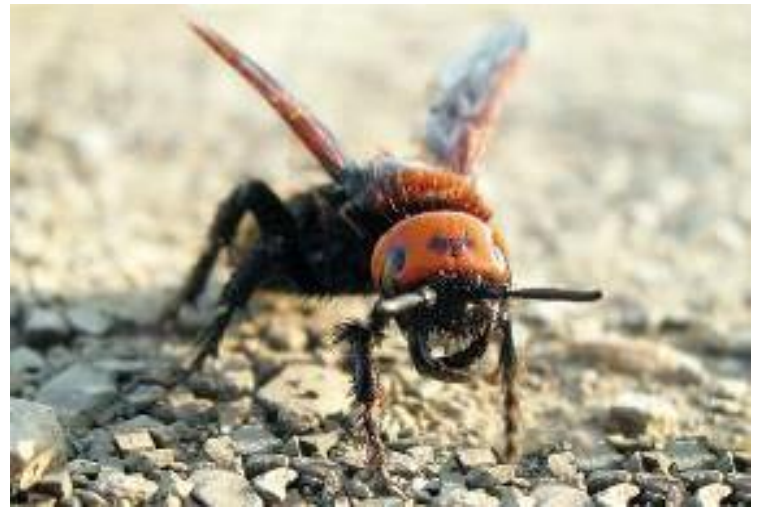

4

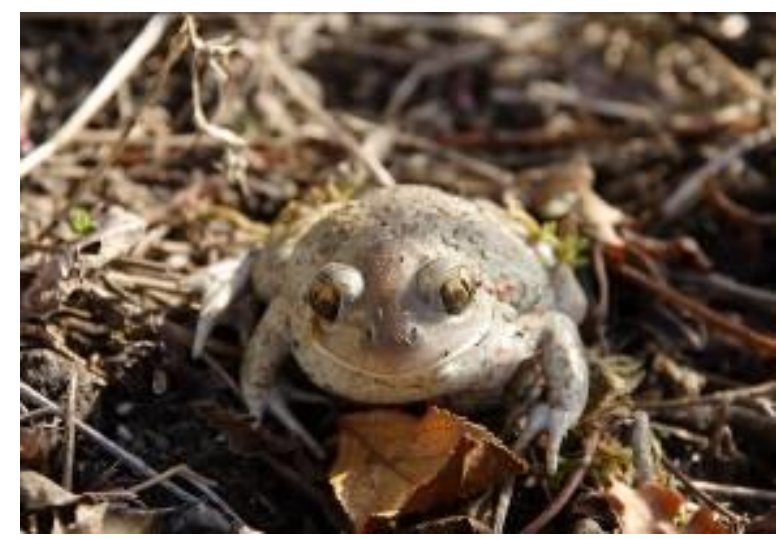

6

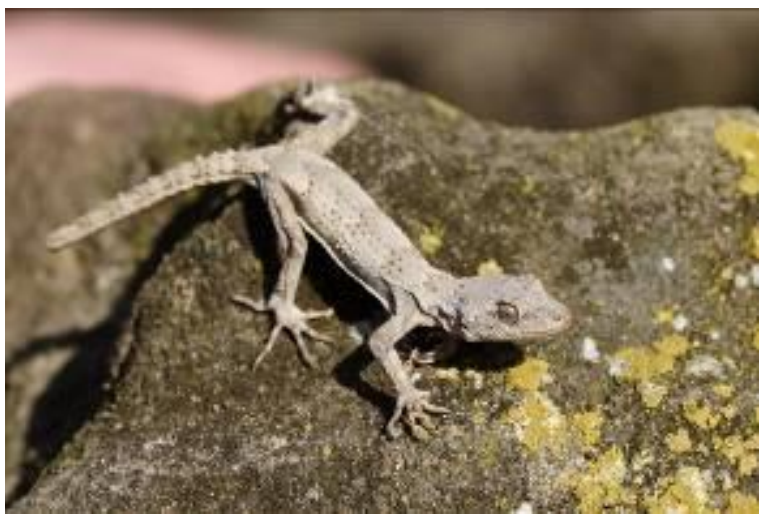

8
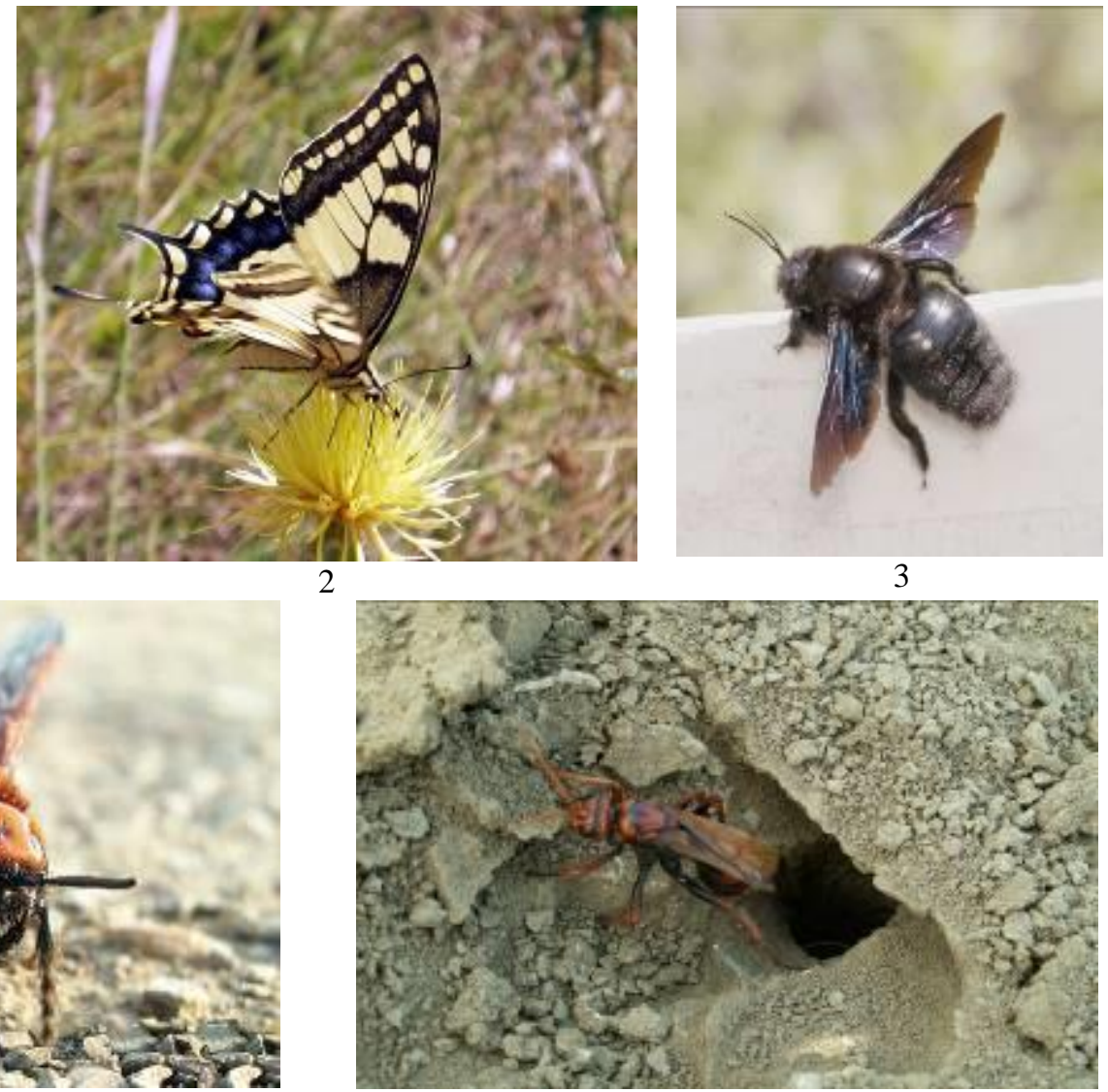

5

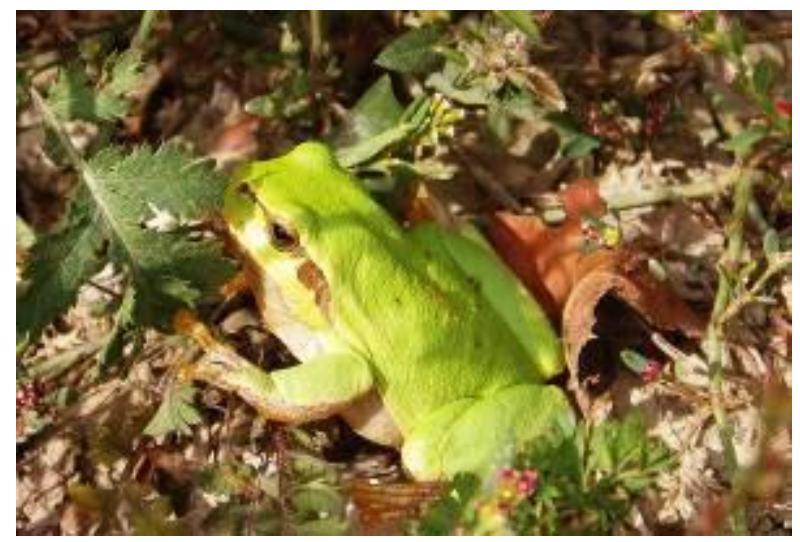

7

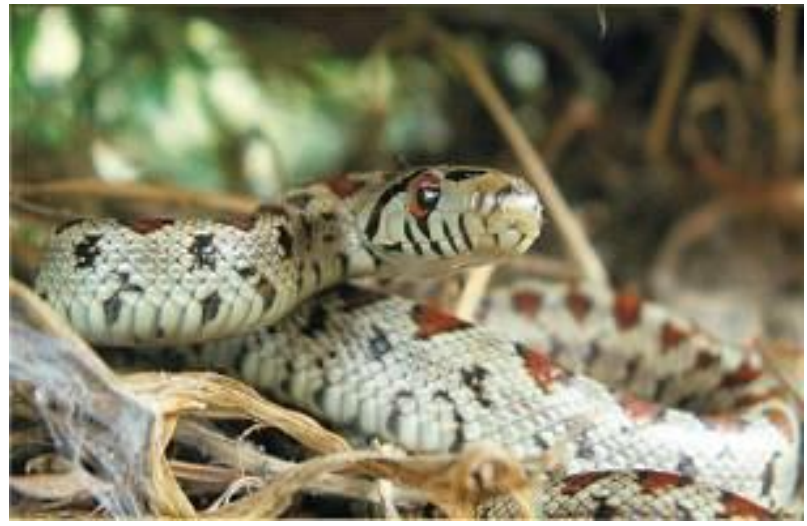

9

Рис. 5. Объекты животного мира Карадагского природного заповедника: 1 - мантиспа штирийская, 2 - махаон, 3 пчела-плотник обыкновенный, 4 - сколия-гигант, 5 - криптохил красноватый, 6 - чесночница Палласа, 7 - квакша восточная, 8 - геккон средиземноморский, 9 - полоз леопардовый

Фото: Л.В. Знаменская $(2,6,7,8)$, Р.С. Кветков $(1,3,4,5,9)$. 

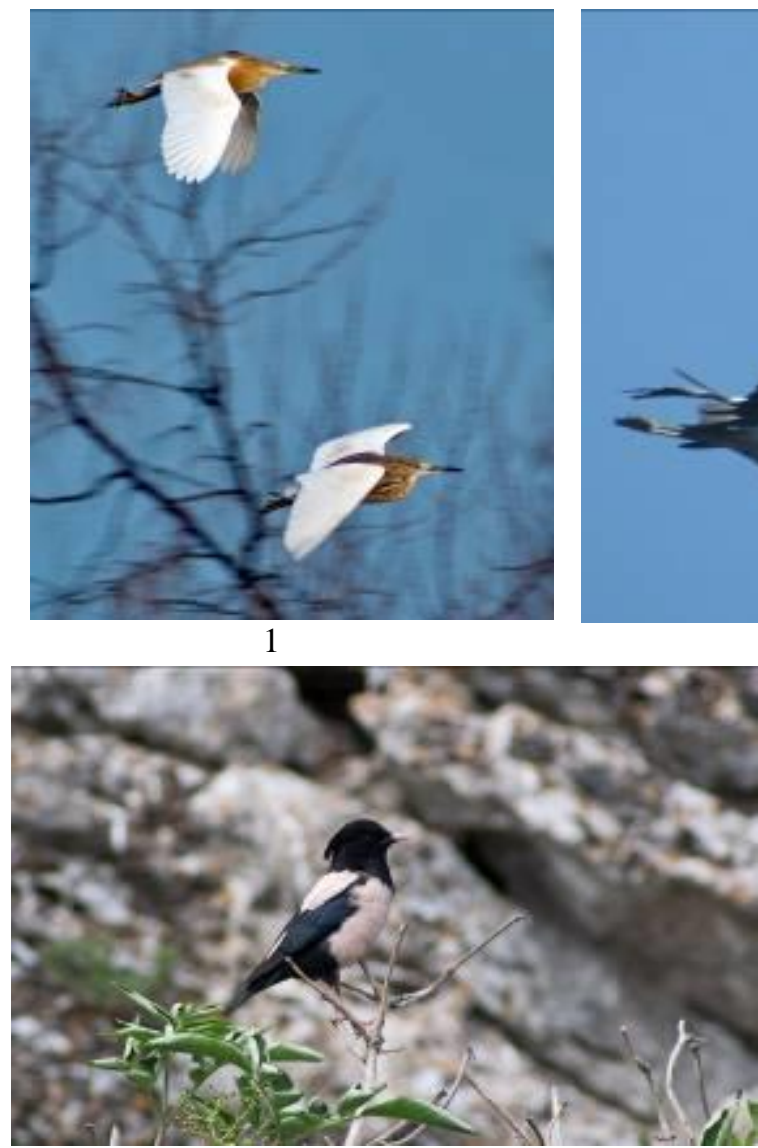

4

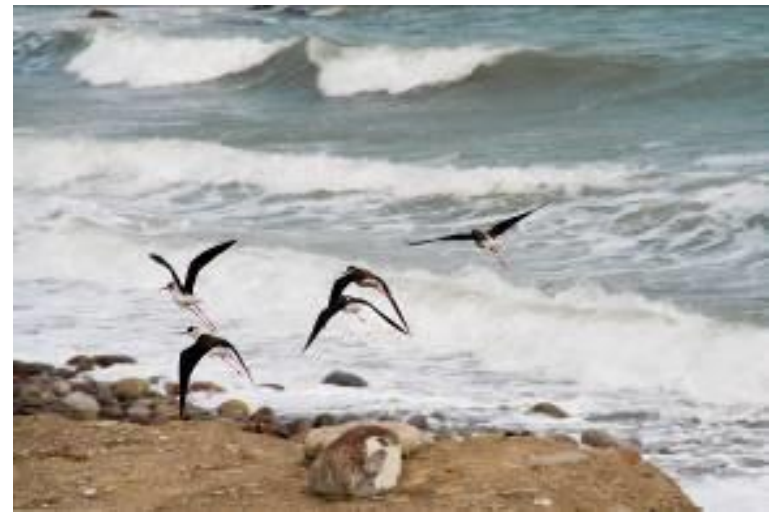

6

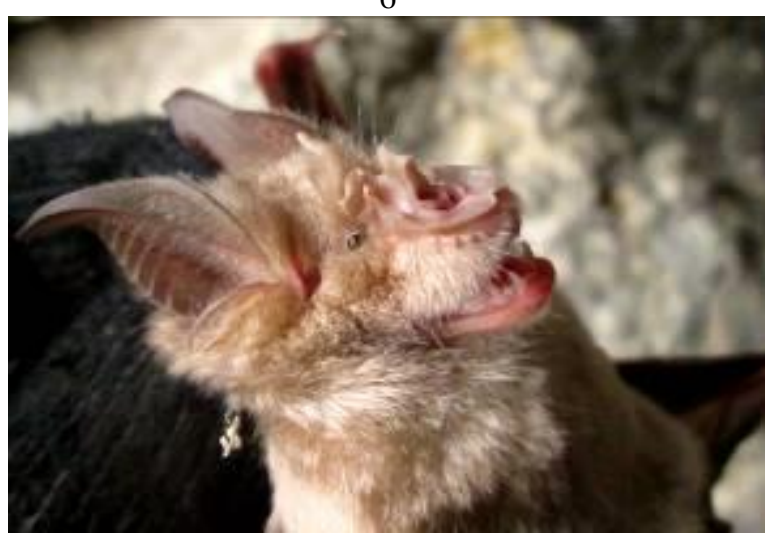

8

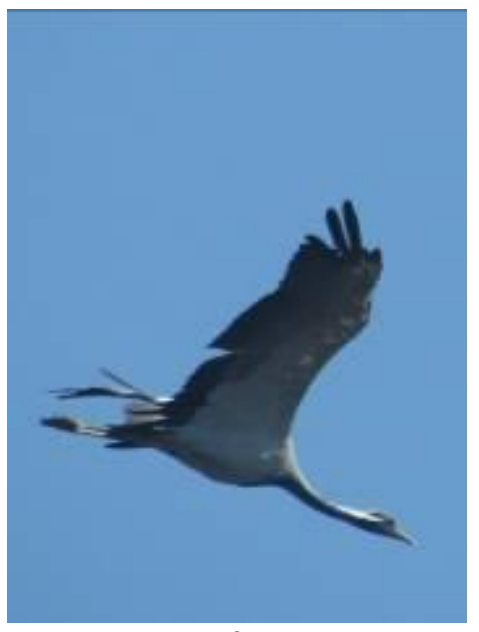

2

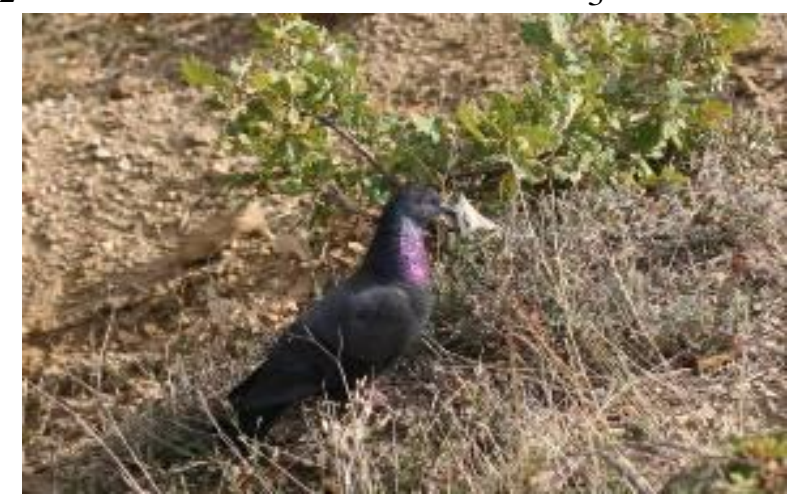

5

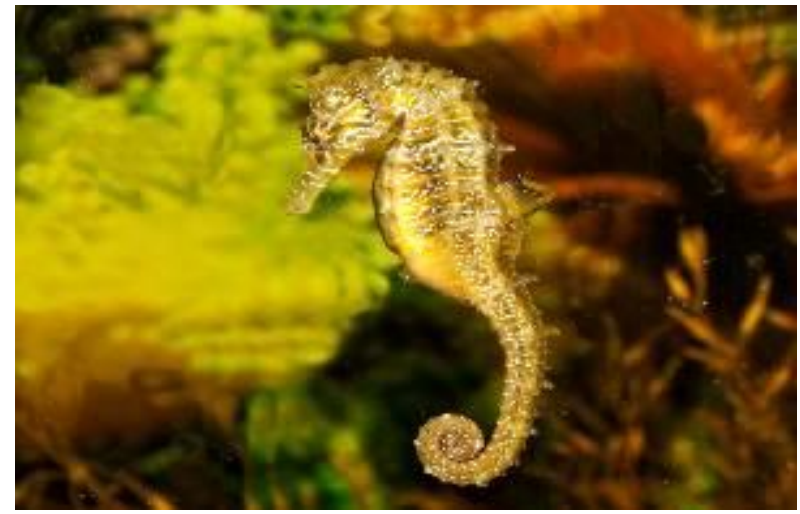

7

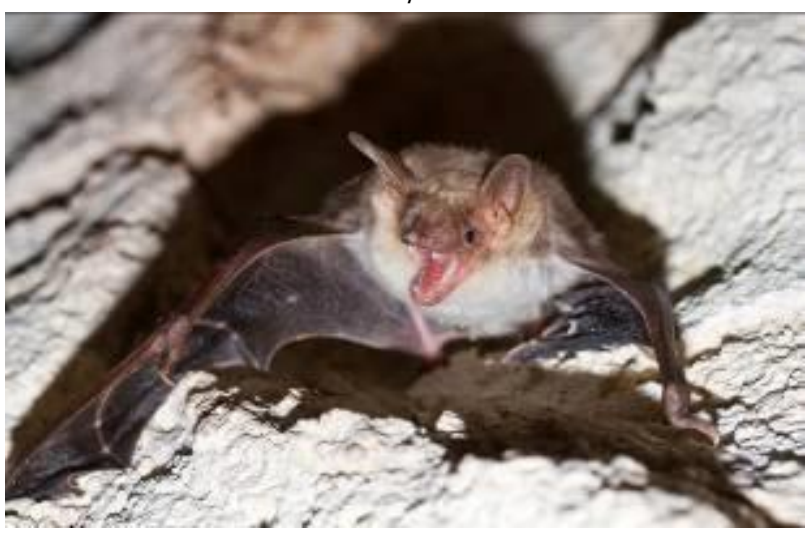

Рис. 6. Объекты животного мира Карадагского природного заповедника: 1 - цапля желтая, 2 - красавка, 3 - баклан хохлатый средиземноморский, 4 - скворец розовый, 5 - голубь сизый, 6 - ходулочник, 7 - морской конек, 8 подковонос большой, 9 - ночница остроухая

Фото: И.С. Алексеев (1), Л.В. Знаменская $(4,5,6,7,9)$, Р.С. Кветков (2, 3), П.В. Оксиненко, О.В. Кукушкин (8). 